
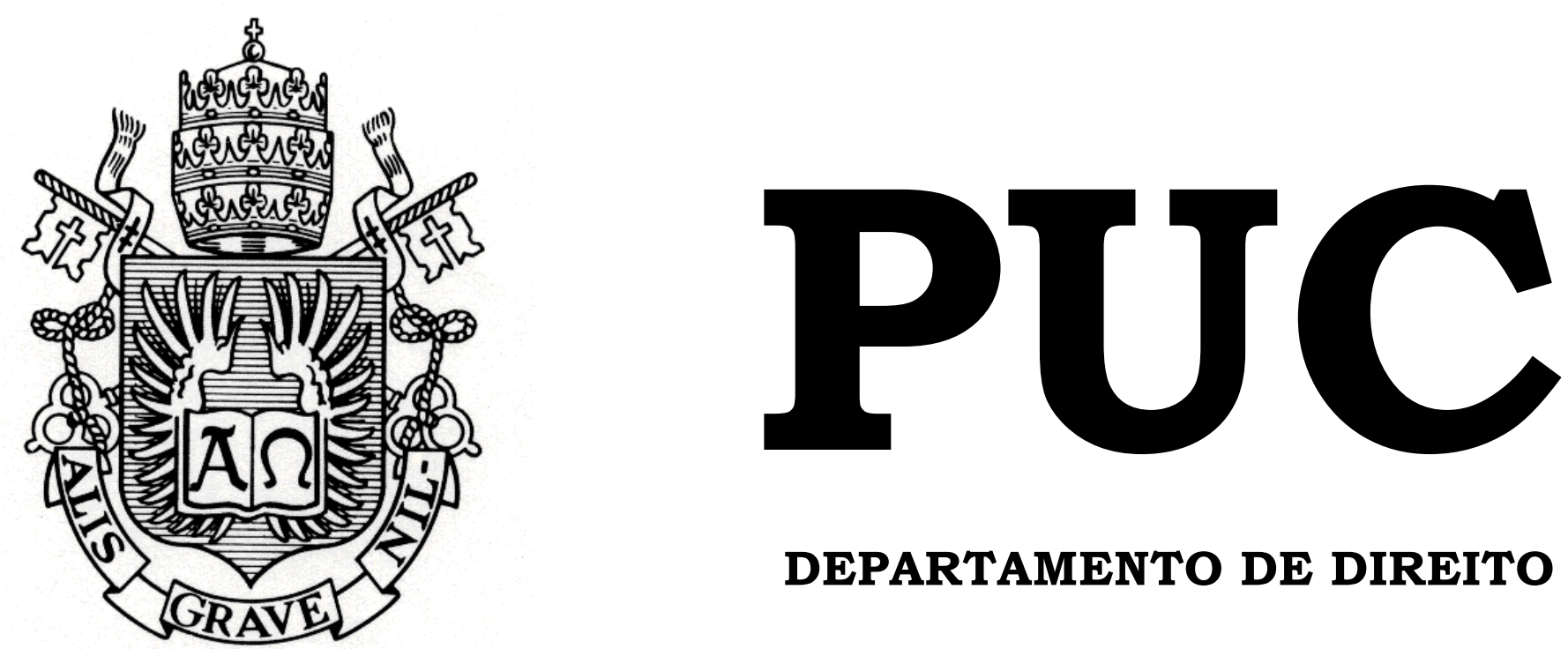

DEPARTAMENTO DE DIREITO

\title{
POLÍTICA CRIMINAL DO INIMIGO NA CIDADE DO RIO DE JANEIRO A PARTIR DOS ANOS 90
}

por

LUCAS GROTH PEREIRA

ORIENTADOR: SÉRGIO CHASTINET DUARTE GUIMARÃES 2015.2

PONTIFÍCIA UNIVERSIDADE CATÓLICA DO RIO DE JANEIRO

RUA MARQUÊS DE SÃO VICENTE, 225 - CEP 22453-900

RIO DE JANEIRO - BRASIL 


\section{POLÍTICA CRIMINAL DO INIMIGO NA CIDADE DO RIO DE JANEIRO A PARTIR DOS ANOS 90}

por

\section{LUCAS GROTH PEREIRA}

Monografia

apresentada

ao

Departamento de Direito da Pontifícia Universidade Católica do Rio de Janeiro (PUC-Rio) para a obtenção do Título de Bacharel em Direito.

Orientador: SÉRGIO

CHASTINET DUARTE GUIMARÃES 


\section{RESUMO}

Esta monografia trata de uma análise crítica a respeito do Direito Penal do inimigo no que tange às suas implicações na política de segurança pública na cidade do Rio de Janeiro. É preciso observar de que forma o discurso de expansão do poder punitivo se materializa e se alastra tanto pelas instituições quanto no imaginário social.

Através de uma análise do que constitui e molda a figura do inimigo, mostramos como esse discurso corrói as garantias fundamentais constitucionalmente asseguradas e o perigo de sua legitimação para o Estado de Direito. Especificamente no cenário do Rio de Janeiro, o Direito Penal do inimigo atua através do modelo bélico utilizado na segurança pública e molda os discursos de lei e ordem além de legitimar o extermínio da população excluída.

Por fim, apontamos diretrizes gerais que podem servir de alternativa para um Estado de Direito que abandone a noção do inimigo, promovendo e respeitando as garantias fundamentais e os Diretos Humanos.

\section{PALAVRAS-CHAVE}

Direito Penal do inimigo; Segurança pública; Traficantes de drogas; Unidades de Polícia Pacificadora; Favela; Direitos Humanos; Política de segurança; Política criminal; Rio de Janeiro. 


\section{SUMÁRIO}

INTRODUÇÃO.........................................................................................4

CAPÍTULO 1 - BREVE CAMINHAR HISTÓRICO. ................................10 CAPÍTULO 2 - DIREITO PENAL DO INIMIGO EM GÜNTHER

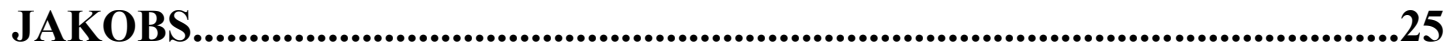

CAPÍTULO 3 - OS INIMIGOS DO RIO DE JANEIRO.............................33

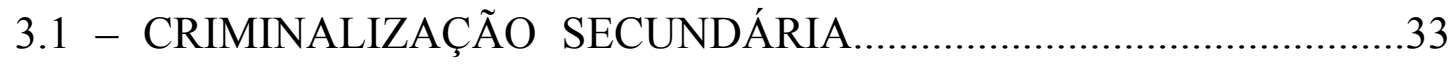

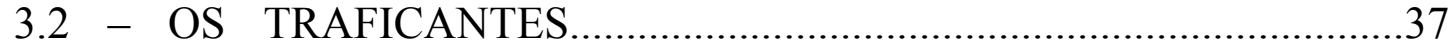

3.3 - POLÍTICA NEOLIBERAL DE DIREITOS HUMANOS.......................43

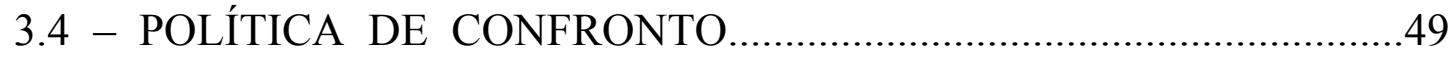

3.4.1 - O GOLPE NOS DIREITOS HUMANOS...........................................49

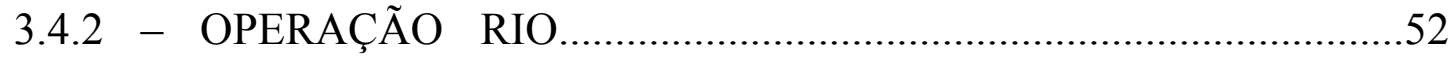

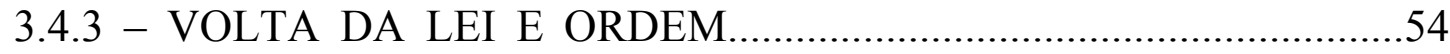

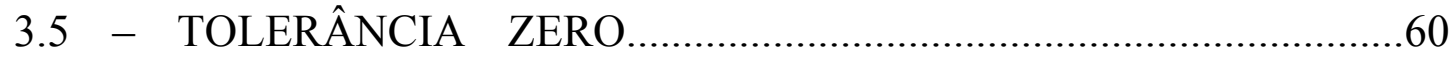

3.6 - UNIDADES DE POLÍCIA PACIFICADORA (UPPs).......................64

3.6 .1 - se vis pacem, parabélum..........................................................................64

3.6 .2 - OCUPAÇÃO.................................................................................

CAPÍTULO 4 - PROPOSTAS DE CONTENÇÃO DO PODER PUNITIVO........................................................................................................................77

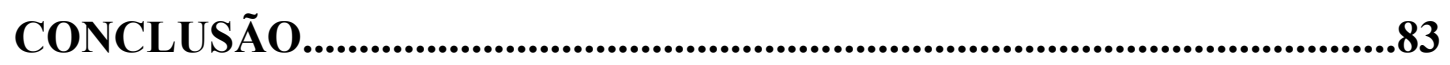

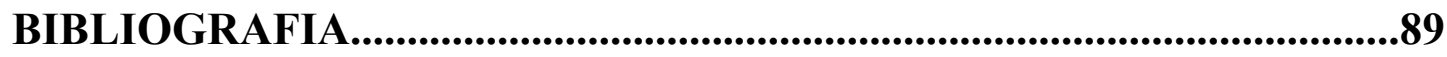




\section{INTRODUÇÃO}

O presente trabalho resulta da necessidade de não se limitar à mera discussão dogmática sitiada em uma torre de marfim, incapaz de dialogar com a realidade e de perceber os fenômenos atuais, seja em escala regional ou global. A teoria da pena não passa de um devaneio teórico que nunca logrou materializar-se. Mesmo assim, ainda é ensinada nas academias dogmaticamente como algo tão óbvio e elementar quanto a lei da gravidade. Principalmente na seara do Direito Penal, hoje, mais do que nunca, é preciso juristas que não se limitem a reproduzir uma dogmática ignorante à realidade. Mais do que isso, é preciso que esses mesmos juristas sejam críticos e capazes de produzir um novo discurso que não seja baseado nos dogmas tradicionais. Um discurso que sirva, no mínimo, para conter a expansão punitiva. Para isso, é necessário um estudo interdisciplinar. Não é suficiente que o jurista se debruce tão somente sobre as leis e doutrina, mas é preciso socorrer-se da sociologia, criminologia, história e filosofia. Dialogar com todas as outras áreas do saber que de alguma forma tocam aspectos comuns sobre o tema é o primeiro passo para uma teoria que consiga ser útil e transformadora.

Todo Estado Democrático leva consigo uma semente de Estado de Polícia que germina e exerce uma força de expansão consumindo-o como uma erva daninha que pode devastar um jardim inteiro caso seja deixada de lado. É preciso conter o poder punitivo do Estado, pois a sua expansão, necessariamente, nos leva de um Estado Democrático para um Estado de Polícia absoluto. A história nos adverte reiteradamente a respeito da catástrofe que esse descuido resulta. 
Este trabalho terá como objetivo um exame acerca do Direito Penal do Inimigo e suas implicações na política de segurança pública no Estado do Rio de Janeiro atualmente. Para tanto, será necessário, inicialmente, traçar um histórico desse fenômeno que foi adaptando-se com o passar dos séculos de acordo com as necessidades que os cenários políticos estabeleceram, porém sem nunca perder sua essência encontrada na figura do hostis.

Desde os tempos de Roma, já se podia verificar um outro capaz de prejudicar e ameaçar a sociedade. No entanto, é com as formulações contratualistas da teoria política que se constroi a ideia de inimigo com as características que temos hoje. Todas as formulações seguintes são derivações das primeiras e que tendem a remodelar o hostis de acordo com a contingência tanto do poder punitivo como do cenário político, de acordo com os conhecimentos adquiridos, principalmente pelo positivismo e iluminismo dos séculos XVIII e XIX. Cabe ressaltar também, que o confisco do conflito pelo Estado é condição essencial para o desenvolvimento do poder punitivo como conhecemos hoje e da legitimação da figura de hostis dentro da própria dogmática jurídica - mesmo que escondida.

A consequência máxima da expansão do poder punitivo foi protagonizada pelos regimes autoritários do século XX. A doutrina do Nacional-Socialismo, do fascismo italiano e do regime stalinista da ex-URSS nos mostra o quão irracional pode ser o poder punitivo, levando ao inexorável extermínio de grandes massas por diversos motivos. 
Após o fim da Segunda Guerra Mundial e a percepção do que a expansão do poder punitivo causa em última instância, naturalmente temos um recuo dessa tendência punitivista. O Estado de Bem-Estar Social passa a ser uma arma da sociedade capitalista para impedir o avanço da União Soviética, assim como o plano Marshal de reconstrução de Europa destruída. No entanto, isso em nada faz a figura do hostis sumir. Pelo contrário, é remodelado: de um lado do globo passa a ser o comunista e do outro, passa a ser o inimigo da revolução. Mais uma vez temos uma adaptação do poder punitivo para gerar uma nova figura de inimigo e justificar sua expansão.

Agora o inimigo é outro: não mais o comunista subversivo, mas o traficante desalmado que mata pessoas a sangue frio e vende substâncias tóxicas mais prejudiciais do que quaisquer outras drogas legais - ou pelo menos assim nos querem fazer crer. Para justificar uma política colonialista americana, é necessária uma divisão básica entre produtores (perigosos, inimigos) e consumidores (vítimas que precisam ser defendidas). A partir dessa divisão, são elaboradas leis, institutos jurídicos e políticas de segurança pública que mais se assemelham a um plano de guerra do que efetivamente a políticas de segurança. Especialmente na América Latina, as medidas cautelares e a antecipação das penas passam a ser a regra do sistema penal. As áreas onde se encontram os mais pobres, que carregam até hoje o peso da escravidão somado à exclusão social de não se enquadrarem numa sociedade de consumo, passam a ser território inimigo. A figura do traficante se resume ao jovem, negro, pobre, morador da favela, que, na verdade, é a parte mais frágil de toda a cadeia de drogas ilícitas, sendo considerado o mais perigoso dos inimigos. Esses punidos e mal pagos, como no título do livro de Nilo Batista, precisam ser exterminados ou a sociedade pode perecer. Eis o novo discurso do poder punitivo. 
No Rio de Janeiro, as políticas de segurança pública são abertamente beligerantes, voltadas para exterminar um inimigo perigoso que pode ser considerado uma "não-pessoa". Dessa forma, não há que se falar nas garantias que o direito penal do cidadão estabelece, mas aos perigosos e inimigos devese aplicar a contenção ou a eliminação a todo custo. Não raro, temos o discurso da segurança pública se colocando em oposição direta aos direitos humanos, como se um fosse o perfeito inverso do outro. Vemos a mídia manipular a opinião pública no intuito de causar pânico para que se legitimem execuções sumárias. Hoje, a condição de traficante justifica qualquer procedimento de tortura, não somente àquele que é rotulado de traficante, como também aos seus próximos - familiares e amigos. Afinal, o amigo do meu inimigo também é meu inimigo.

Nos últimos anos, podemos observar um aumento expressivo do poder punitivo pelo crescimento da população carcerária e pelas ações que as instituições policiais executam sem que maiores indagações sejam feitas. Mandados de busca e apreensão coletivos, reiteradas denúncias de tortura, aumento exponencial de autos de resistência e de desacato, tudo isso nos indica o crescimento do Estado de Polícia que é legitimado pela sociedade. Na "retomada" do Complexo do Alemão, foi hasteada a bandeira brasileira no alto do morro. O hasteamento da bandeira nada mais significa que a tomada de um território.

Em seguida à ocupação do campo inimigo, o Estado logo resolveu providenciar Unidades de Polícia Pacificadoras (UPPs): centros onde a polícia monitora e administra o território conquistado. $\mathrm{O}$ tratamento ao qual a população é submetida nesses lugares só seria imaginável, dentro do 
ordenamento brasileiro, caso fosse decretado estado de sítio previsto na constituição. Toque de recolher, revistas diárias, mitigação do direito de ir e vir, proibição de eventos culturais, entre outros, passaram a ser a rotina das favelas "pacificadas".

No entanto, a violência não diminuiu nessas áreas. Pelo contrário, como já dito, o número de autos de resistência cresce exponencialmente, assim como as denúncias por desacato. Mesmo com essa situação imperante nas comunidades, o discurso punitivo continua sua expansão. A mídia, mais uma vez, usa sua influência para aterrorizar a população e dizer que o perigo ainda aumenta. Pautas como criação de novos tipos penais, penas mais graves e a diminuição da maioridade penal são temas que atualmente fazem parte do cotidiano dos cariocas.

Em meio a todo o expansionismo punitivo, precisamos lutar pela contenção do poder de punir e, acima de tudo, prezar pelas garantias individuais. Nada disso, porém, será efetivo se continuarmos aceitando a ideia de inimigo. Sendo assim, as teorias estáticas de contenção do poder punitivo são ineficientes, pois não levam em consideração que esse poder se adapta às condições da sociedade e encontra, novamente, um canal por onde passar. Esse foi o equívoco do professor Jakobs em sua tese. O caminho é deslegitimar a própria existência do conceito de inimigo para que possamos criar uma teoria dinâmica de contenção do poder punitivo e, dessa forma, construir um Estado verdadeiramente democrático onde o status de cidadão seja estendido a todos e a todas sem restrições. Em última instância, reconhecer todos como cidadãos e negar a ideia de inimigo são as condições essenciais para a efetivação dos 
direitos humanos e a garantia de que o Estado não exercerá seu ius puniendi de forma arbitrária contra os mais fracos.

Essa tarefa, no entanto, não será, de forma alguma, fácil ou tranquila. Já dizia Jhering: "A paz é o fim que o direito tem em vista; a luta é o meio que se serve para o conseguir. (...) O direito não é uma pura teoria, mas uma força viva." ${ }^{1}$ Dessa forma, fica claro que a contenção do poder punitivo não pode se dar somente pelo viés jurídico, mas, como foi dito anteriormente, necessita da ajuda de todas as outras áreas do saber que tenham algum diálogo com o tema e que possam sempre ajudar, acrescentando, na elaboração de uma teoria capaz de conter a expansão do poder punitivo.

Mesmo o trabalho sendo árduo e esta sendo uma pequena contribuição em um oceano de pensamentos, ideias e opiniões, a mais tímida das ações pode ser essencial. Um antigo ditado chinês diz: "um único grão de arroz pode virar a balança" e a maior das caminhadas começa com o primeiro passo.

\footnotetext{
${ }^{1}$ JHERING, Rudolf von. A luta pelo Direito. Rio de Janeiro: Forense, 2011.
} 


\section{CAPÍTULO 1 - BREVE CAMINHAR HISTÓRICO}

Antes de apontar aqueles indivíduos ou grupos que são tratados como inimigos e as decorrentes implicações na segurança pública do Estado do Rio de Janeiro resultantes da atribuição desse status, é preciso, primeiramente, mesmo que de forma breve, entender o que significa inimigo. Dizendo de outra forma, é necessário saber o que é um inimigo, onde nasce e como se desenvolve essa ideia, antes de analisar seus desdobramentos na práxis do exercício real do poder punitivo.

Precisar o nascimento de uma ideia ou um conceito pode ser uma tarefa extremamente complicada, principalmente se estamos falando de algo tão vago, aberto e contingente como é o inimigo. No entanto, podemos dizer que a sua essência tem origem ainda no direito romano ${ }^{2}$ e, apesar de todo o desenvolvimento do Direito Penal, da ciência política e das mais diversas roupagens que se desenvolveram em torno dessa ideia ao longo da história, seus alicerces podem ser verificados como os mesmos dados pelos antigos romanos. Em outras palavras, os romanos criaram a ideia de inimigo que, ao longo da história, foi sendo reutilizada e readaptada de acordo com o cenário político e filosófico da época, porém sem jamais perder sua essência.

O inimigo remonta então à figura romana do hostis, que era dividido em outras duas subcategorias, quais sejam, o hostis alienigena e o hostis judicatus.

\footnotetext{
${ }^{2}$ ZAFFARONI, Eugenio Raúl. O inimigo no direito penal. Rio de Janeiro: Revan, 2007. p, 21.
} 
O primeiro dizia respeito ao direito das gentes. Já o segundo, era aquele declarado hostis a partir de uma decisão do Senado. Essa decisão fazia com que ao indivíduo fosse atribuído o status de inimigo público.

O hostis alienigena, como a própria palavra indica, é aquele que vem de fora da sociedade, o estrangeiro. Não se compreende o estrangeiro já que seus costumes, hábitos, práticas e história são diferentes. Com ele a comunicação não é possível, pois sua língua é diferente. Ele incomoda o poder instituído por ser um estranho e inspira medo e desconfiança nas pessoas visto que é desconhecido, sendo assim, passa a ser potencialmente perigoso.

O hostis judicatus é aquele que foi designado como perigoso pelo Estado. É um inimigo declarado, entendido como dissidente. Essa condição de hostis judicatus fazia com que ao cidadão romano pudessem ser impostas medidas semelhantes às impostas aos escravos. ${ }^{3} \mathrm{Ou}$ seja, tirava do cidadão qualquer proteção derivada do reconhecimento do que, naquela época, corresponderia ao que entendemos por pessoa.

Essas linhas gerais do que os romanos entendiam por hostis, seja ele um estranho à sociedade, seja ele alguém assim declarado pelo poder instituído, são a essência que vai sobreviver durante a história e permear todos os discursos penais de forma mais ou menos declarada, a depender da contingência de cada lugar e tempo.

${ }^{3}$ Ibid. p, 23 - 24. 
O resultado dessa atribuição de um status de inimigo é um tratamento que, mais do que ignorar, nega ao individuo sua condição de pessoa. Alguns dirão que mesmo quando entendido como inimigo, os ordenamentos jurídicos ainda concedem e reconhecem direitos aos indivíduos tratados de forma diferenciada em virtude de sua periculosidade e somente na medida da necessidade correspondente à periculosidade e virtual dano que o mesmo possa causar. Sendo assim, não há que se falar na negação do status de pessoa. No entanto, como bem disse Zaffaroni:

A estrita medida da necessidade é a estrita medida de algo que não tem limites, porque esses limites são estabelecidos por quem exerce o poder. Como ninguém pode prever exatamente o que algum de nós - nem sequer nós mesmos - fará no futuro, a incerteza do futuro mantém em aberto o juízo de periculosidade até o momento em que quem decide quem é o inimigo deixa de considera-lo como tal. Com isso, o grau de periculosidade do inimigo - e, portanto, da necessidade de contenção - dependerá sempre do juízo subjetivo do individualizador, que não é outro senão o de quem exerce o poder ${ }^{4}$

Dessa forma, o que está em jogo não é propriamente a quantidade de direitos que são preservados quando um indivíduo é considerado perigoso, mas a qualidade do direito. $\mathrm{O}$ fato de tratar uma pessoa em função de sua periculosidade e, portanto, instrumentalizá-la é o que vai definir se a mesma é tratada ou não com as características substanciais de pessoa.

Alguns momentos na história foram - e de alguma forma ainda são muito importantes no desenvolvimento da noção de inimigo e, consequentemente, na forma de tratar com o mesmo. Um desses momentos se dá na revolução inquisitorial. Após a queda do Império Romano, durante o

\footnotetext{
${ }^{4}$ Ibid. P, 25.
} 
feudalismo na Europa Ocidental, a resolução de conflitos acontecia basicamente por forma das ordálias. Nessa maneira de conhecimento da verdade, as partes lutavam e Deus expressava sua decisão garantindo a vitória a um dos combatentes. Desse modo, o juiz era basicamente um árbitro que se incumbia de que as regras do confronto fossem observadas para que a expressão clara da vontade de Deus não fosse desvirtuada.

Com a volta do poder punitivo nos séculos XII e XIII, as ordálias começam a ser substituídas pela inquisitio. Esse método passa a ser a "forma jurídica da verdade". ${ }^{5}$ Aqui, Deus não mais manifesta a sua vontade e aponta a verdade através do vencedor, mas o inquisidor passa a interrogar um objeto de conhecimento e vai, assim, obter a verdade. É nesse momento que nasce a figura do "procurador do rei", que, quando um crime acontecia, entrava em cena alegando que o delito gerou um dano ao próprio soberano. Essa prática leva ao confisco do conflito e, ao invés de uma única vítima, passa-se a ter duas: a vítima e o Rei. Por fim, o infrator ou delinquente passa de uma parte do conflito a objeto do qual se extrairá a confissão, ou seja, a verdade. Dessa maneira, se institui a tortura como prática de conhecimento até que se chegue à verdade alcançada, em última análise, pela confissão. Assim, tortura-se até que se chegue à verdade. Todo um conhecimento passa a ser construído e os métodos de tortura ficam cada vez mais elaborados a fim de que se chegue à confissão sem que o interrogado morra no processo.

Um sujeito cognoscente passa a perguntar ao objeto que vai responderlhe tudo a seu respeito, fazendo com que o sujeito chegue à verdade através das

\footnotetext{
${ }^{5}$ ANITUA, Gabriel Ignacio. Histórias dos pensamentos criminológicos. Rio de Janeiro: Revan, 2008. $\mathrm{P}, 37$.
} 
respostas do objeto inquirido. A crença aqui é que, se ao objeto for perguntado da maneira correta, a verdade pode ser sempre alcançada. Se o objeto não ofereceu as respostas necessárias ou suficientes, ainda é possível acessá-las, e os obstáculos ao alcance da verdade devem ser superados ou eliminados.

A esse novo método de conhecimento da verdade ainda adiciona-se que a ofensa, agora, não é mais dirigida à vítima, mas, acima de tudo, dirigida ao soberano, que, sendo um representante do divino no mundo material, confisca o conflito para si. No próximo passo, a verdade e o conhecimento passam a ser relacionadas ao bem, uma vez que Deus sabe a verdade e a ignorância, por inverso, passa a ser o mal. Sendo assim, o acesso à verdade é crucial e, mais do que isso, o saber do soberano é imprescindível, pois o mesmo representa o divino e este tudo sabe como expressão de sua bondade. Se o conhecimento e o saber são expressão da bondade e verdade, qualquer obstáculo que impeça essa trajetória é necessariamente mau e ignorante, podendo - e até mesmo devendo - ser eliminado. Por isso, tudo aquilo praticado em nome do saber é automaticamente praticado em função do bem e todo obstáculo será, necessariamente, por pensamento inverso, mau. Ou seja, os obstáculos que se projetam sobre o saber do sujeito são inimigos do bem.

Um pouco adiante temos o surgimento das teorias do contrato social que vão legitimar o Estado a partir da ideia de que os homens antes dispunham de total liberdade, mas que, para benefício mútuo, abrem mão de parte dessa liberdade para que possam ser protegidos e sair de um estado de guerra de todos contra todos. Um dos mais importantes pensadores do contratualismo foi Thomas Hobbes que, por sua vez, tinha intenção de separar o Estado da Igreja. Para este autor, os homens se encontram em um estado inicial onde não há 
direitos, apenas impera a vontade do mais forte. O contrato é realizado entre os súditos que entregam todo poder ao soberano e, como esse é o único meio de evitar a guerra, a submissão deve ser total. Sendo assim, não se pode ir contra o soberano, não há que se falar em direitos oponíveis contra ele, já que isso significaria voltar ao estado de guerra de todos contra todos. Então, quem resiste ao soberano é um inimigo, visto que destruirá a paz e fará voltar o caos. É importante ressaltar que, para Hobbes, não é qualquer delito que transforma seu autor em inimigo, apenas aqueles contra o soberano, pois dessa forma o indivíduo rompe com o pacto social por sua própria vontade.

Um segundo autor que muito influenciou a teoria política e a noção de Estado foi John Locke. Diferentemente de Hobbes, Locke entende que mesmo no estado de natureza os homens tinham direitos. Ao mesmo tempo, este autor entende que o estado de natureza não era necessariamente um estado de guerra de todos contra todos - embora a guerra pudesse sempre ocorrer -, mas a paz era também uma realidade. O que sustentava seu pensamento era a ideia de que antes mesmo de haver um Estado, havia sociedade civil e, através dela, os indivíduos formavam o Estado por meio de um pacto social. Pode parecer uma singela diferença, porém seus desdobramentos acabam por gerar um resultado inteiramente diferente. Sendo a sociedade civil anterior ao Estado, os indivíduos conservam parte de seus diretos que precedem o próprio Estado. $\mathrm{O}$ direito de resistência ao soberano é um direito inato dos indivíduos, ou seja, acaba-se com a noção de um Estado absoluto.

Quanto à ideia de inimigo, este será o ponto nevrálgico das implicações. Em Hobbes, inimigo é qualquer um que vá contra o soberano, uma vez que não existem direitos precedentes ao pacto social e a desobediência ao soberano é 
necessariamente uma volta ao estado de natureza e de guerra permanente. Para Locke, aquele que exerce um direito de resistência legítimo defendendo direitos pretéritos ao pacto derivados da sociedade civil o faz contra a opressão do Estado e não pode ser entendido como inimigo, mas o soberano que abusa de seu poder deve ser deposto.

Isso não quer dizer, porém, que Locke não admita a figura do inimigo. Para ele, apenas a resistência legítima pode ser oposta ao soberano. Aquele que se opõe ao Estado de maneira ilegítima não o faz protegido pelo direito de resistência, dessa forma, ainda constitui um inimigo. Ou seja, apesar de não concordar com a ideia de Estado absoluto e admitir enfaticamente hipóteses de resistência contra o poder instituído, Locke ainda aceita a ideia de um inimigo que rompe com o pacto ou que seja estranho a ele.

No âmbito da secularização do Estado, a noção de que o criminoso teria cometido uma ofensa contra o rei e, consequentemente, contra Deus, se desloca para um entendimento de que o delito seria a quebra do contrato. Cometer um delito seria como ir contra as cláusulas contratuais que os indivíduos assinaram para entrar no Estado e seu descumprimento era uma ofensa ao Estado em si. O inimigo deixa de ser um inimigo do rei passando a ser de toda a sociedade. Quando comete o delito, o delinquente causa um mal indireto a todos os outros signatários do contrato.

As teorias contratualistas mudaram radicalmente a teoria política, a noção de Estado e, consequentemente, a organização social. Em relação à ideia de inimigo, porém, é, por vezes, até mais severa. O delinquente antes não 
cometia um ato contra a sociedade, mas contra o rei. Agora, o inimigo causa um mal para seus pares. Por sua própria vontade, rompe com um pacto feito com os demais, minando a liberdade e levando a sociedade para potencial colapso e volta a um estágio pré-Estado que pode ser mais ou menos violento dependendo do autor. $\mathrm{O}$ inimigo passa a ser, na teoria política, ainda mais perigoso do que antes.

Caminhando um pouco mais na história chegamos à Revolução Industrial. Sem dúvidas, esse momento é um marco que traz consigo transformações muito importantes quanto às relações sociais. No entanto, no que tange ao inimigo, podemos dizer que há apenas uma adaptação funcional das práticas anteriores. Há o surgimento de uma nova classe social, qual seja, os industriais e comerciantes. Estes, por sua vez, precisam minar o poder instituído da nobreza e clero e, assim, tentam redefinir o poder punitivo que constituía uma das armas que os dominava. Formalmente falando, temos alguns avanços no direito, principalmente no que tange os direitos dos iguais. Em quase nada, no entanto, se altera a noção do hostis e muito menos na ampliação do círculo dos iguais, que é acrescido dessa nova classe, mas que em sua totalidade continua sendo uma parcela ínfima da sociedade.

É até possível que no novo cenário dos avanços industriais e nova dinâmica social possamos até mesmo ser levados a pensar que há uma melhora qualitativa no status de inimigo. A pena de morte passa a ser limitada a crimes muito graves, as penas corporais são reduzidas e praticamente substituídas pela pena privativa de liberdade. Isso, porém, em nada mudou a lógica e essência do tratamento ao inimigo. A eliminação física continua e, devido ao novo modelo de sociedade trazida com a Revolução Industrial e a concentração 
urbana, aumenta exponencialmente. Além disso, como já apontado antes, não é exatamente a forma como se pune o inimigo que corresponde à sua essência, mas sim seu entendimento como ente perigoso.

Com isso, a estratégia do poder punitivo foi o encarceramento inserido no panoptismo ${ }^{6}$ e, junto com ele, vem toda a ortopedia moral de um modelo utilitarista de sociedade que a época necessitava para poder criar trabalhadores nas fábricas e, ao mesmo tempo, se livrar dos dissidentes e dos indesejáveis. Concomitantemente, temos o surgimento de uma medicalização da sociedade. A outra forma de gerenciamento dessa nova sociedade se dava através da higienização e do controle da loucura, cujas instituições de saber serão os asilos, manicômios e hospitais. Uma sociedade de controle baseada no modelo panóptico começa a surgir.

Com os limites que foram traçados a partir do liberalismo, o novo paradigma jurídico impedia que a prisão fosse o lugar onde se despejasse todos os perigosos, visto que sua função era de castigo e não de prevenção. Por esse motivo, o paradigma médico ganha importância nessa sociedade. Com o status de ciência e, consequentemente, de verdade indiscutível, o médico poderia dizer quais são aqueles nocivos e potencialmente perigosos à sociedade sob uma perspectiva médica higienizadora de controle da saúde pública. Os inimigos eram perigosos, pois podiam contagiar os outros e trazer consigo enfermidades graves sejam elas físicas, morais ou psíquicas.

\footnotetext{
${ }^{6}$ FOUCAULT, Michel. Vigiar e punir. Rio de Janeiro: Vozes, 2010.
} 
Segundo a visão higienista, qualquer forma de anormalidade deveria ser tratada com a finalidade de cura. No campo da moral, os males eram o alcoolismo, vagabundagem, promiscuidade. A delinquência não era diferente das enfermidades, mas apenas uma manifestação diversa.

No campo da criminologia, o delito será entendido como doença. $\mathrm{O}$ delinquente é uma célula doente no corpo social e a delinquência, uma doença grave que pode levar a sociedade ao colapso, assim como um corpo que tem uma infecção generalizada. Do criminoso não se deve exigir retribuição do mal causado, mas como doente deve-se curá-lo e como doença deve-se eliminá-la.

Com essa imagem é que se formará a ideia de que o criminoso sofre de uma doença psíquica. O número de "loucos" era assustador, fato que levou Machado de Assis a se perguntar de forma crítica sobre a questão e escrever um de seus contos mais conhecidos: $O$ alienist ${ }^{7}$, em que um médico, depois de internar a cidade inteira no manicômio, acaba por perceber que, se todos são loucos, talvez a sua condição de sanidade seja a verdadeira loucura.

Com tudo isso, podemos perceber que, apesar das profundas mudanças sociais na dinâmica urbana que se segue com a Revolução Industrial, há apenas uma nova roupagem ao tratamento dado ao inimigo. O discurso, por óbvio, se desloca de um indivíduo do qual se exige retribuição e, consequentemente, castigo para um que deva ser curado. Porém, o inimigo continua

\footnotetext{
${ }^{7}$ ASSIS, Machado de. O alienista. São Paulo: FTD, 1999.
} 
essencialmente o mesmo, sem grandes alterações, com exceção daquelas necessárias para o novo discurso criminal que se estabelecia na época.

A primeira metade do século XX foi marcada por duas grandes guerras e episódios marcantes que mudaram o mundo em vários aspectos. Na Rússia, na época União Soviética, temos um Estado totalitário sob a égide de teorias marxistas; na Itália, um Estado que se conclamava herdeiro do Império Romano e, na Alemanha, uma nação recém-formada tentava se reposicionar no mundo trazendo consigo um "espírito do povo" recheado de mitos de superioridade racial.

Conjuntamente a esse espectro político, há o início do processo de globalização, em que o desenvolvimento tecnológico passa a permitir comunicações e transações em escala planetária até então surpreendentes. Isso possibilitou a formação de uma máquina de propaganda com alcance considerável. Não podemos observar o fenômeno dos Estados totalitários, seja no seu contexto político, seja no seu conceito teórico, desvinculado dos acontecimentos do século XIX já acima mencionados. A medicalização, as estruturas panópticas de sociedade e a higienização representam o nascimento do que se desenrola pelo século XX. Foi a partir dessa concepção médica que, misturada aos mitos e ao racismo, surgiram as ideias de superioridade ariana da maneira como foram construídas na Alemanha. Ao mesmo tempo, na então União Soviética, o trabalho era tentar mostrar que o darwinismo era falho e que as ideias de Lamarck $^{8}$ eram as corretas. Afinal, o meio precisava

\footnotetext{
${ }^{8}$ Jean-Baptiste Pierre Antoine de Monet, Chevalier de Lamarck foi um naturalista francês que desenvolveu a teoria dos caracteres adquiridos. A ideia geral do autor era de que o meio ambiente influenciava na evolução das espécies, sendo o a lei do uso e desuso um dos fatores mais importantes do processo evolutivo.
} 
influenciar as espécies. Era preciso provar que a sociedade comunista ou a implementação do socialismo seria capaz de mudar a própria natureza do homem. Em contraposição, a Europa e os EUA precisavam provar a sobrevivência do mais adaptado e do mais forte preconizadas por Darwin, visto que era isso que sustentava - e de certa forma ainda sustenta - a livre concorrência, a meritocracia e todo o sistema capitalista.

Os Estados totalitários da primeira metade do século XX se agarraram ao positivismo como pano de fundo para darem fundamento às suas realizações. No mais, com a justificativa biológica de que alguns grupos eram inferiores, limitados ou até mesmo prejudiciais ao desenvolvimento do povo, aquele pensamento que antes buscava a cura e prevenção de doenças, mesmo que através da segregação e controle dos indivíduos, nesses estados os vê como seres inferiores que são nocivos, perigosos e querem destruir a sociedade. Aqui, há uma pequena diferença que muda a forma de lidar com o inimigo. Antes, o indivíduo doente, seja por uma enfermidade, seja por uma doença psíquica, era um enfermo e sua condição gerava a periculosidade. No entanto, como doente poderia ser tratado, ou seja, a sociedade de alguma forma poderia tratar dos doentes a fim de que o mesmo voltasse a ser saudável, mesmo que, por vezes, esse tratamento seja doloroso e implique em efeitos colaterais.

No caso dos estados totalitários que trazem o racismo através da biologia e teorias evolucionistas, os inimigos são onticamente identificados através de um positivismo proveniente das ideias de Garofalo e não são mais doentes do qual se espera encontrar cura, mas, literalmente, raças inferiores de seres humanos, os quais, por sua condição biológica natural, são nocivos, 
perigosos e ameaçadores, além de impedir o desenvolvimento das raças superiores. Segundo Zaffaroni:

A periculosidade e seu portador (o perigoso) ou inimigo onticamente reconhecível, provenientes da melhor tradição positivista e mais precisamente garofaliana, cedo ou tarde, devido à sua segurança individualizadora, termina na supressão física dos inimigos. O desenvolvimento coerente do perigosismo, mais cedo ou mais tarde, acaba no campo de concentração. ${ }^{9}$

Isso faz com que o inimigo agora deva ser ou neutralizado ou eliminado ao invés de curado. Mais uma vez, percebe-se que a mudança do discurso e os acontecimentos históricos moldam de alguma forma aqueles apontados como inimigos na sociedade. No entanto, a ideia de que há grupos que são de alguma forma estranhos, diferentes e potencialmente perigosos continua a imperar.

No pós Guerra Fria e entrando no século XXI, a configuração política do mundo muda mais uma vez de forma considerável. Com o colapso da União Soviética, os Estados Unidos se consolidam como potência mundial hegemônica. Sem a disputa política da bipolarização do globo, o foco de todo o aparato bélico e desenvolvimento tecnológico militar se perde somente para ser renovado com os traficantes e com os acontecimentos de 11 de setembro de 2001. A partir desse fato, nasce mais uma vez um inimigo tangível que foi chamado de terrorista. A propaganda que os Estados Unidos difundiram para o mundo foi de medo e de que ninguém estava a salvo, que a qualquer minuto outro atentado de proporções catastróficas seria possível e, dessa forma, justificaram uma guerra preventiva trazendo o discurso de caráter preventivo do direito penal.

${ }^{9}$ ZAFFARONI, Eugenio Raúl. O inimigo no direito penal. Rio de Janeiro: Revan, 2007. p, 104. 
Juntamente com esses acontecimentos, o processo de globalização fez com que as fronteiras ficassem cada vez mais perto, mas, ao mesmo tempo, que as realidades econômicas e sociais dos países fossem mais discrepantes, uma vez que a globalização cumpre o papel de abrir as fronteiras para o capital financeiro, interesses econômicos de transnacionais e não para as pessoas. Quando percebemos que os imigrantes da África e do Oriente Médio são, em sua maioria, muçulmanos à procura de melhores condições de vida ou fugindo de guerras, fica nítido que a Europa - apesar de sua união monetária e livre circulação de europeus entre os países - é, e sempre foi, lugar de muita xenofobia, assim como os Estados Unidos, que sempre culparam imigrantes indesejados ou os escravos libertos pelos problemas internos.

Com a força do aparato publicitário, o discurso de periculosidade de alguns grupos ganha uma dimensão planetária, mas, ao mesmo tempo, perde sua construção teórica que dispunha no autoritarismo da primeira metade do século XX. Agora, é um discurso vazio, sem nenhum conteúdo, servindo apenas para incitar emocionalmente medo e repúdio nas pessoas para com o grupo rotulado de inimigo. É o discurso do inimigo trazido pela indústria publicitária que hoje impera na mídia com pouco conteúdo, mas chamadas instantâneas. Não se trata mais de dotar o discurso com conteúdo acadêmico, pelo contrário, o desenvolvimento acadêmico tem chegado à conclusão do exato oposto da ideia de inimigo, tem desmistificado suas origens e desconstruído suas bases, deixando o discurso desnudo em seus preconceitos e ignorância, além de se voltar exatamente para o controle do poder punitivo do Estado. Por isso é que os políticos se agarram tanto ao discurso midiático sem conteúdo, que traz apenas slogans. É perfeitamente possível imaginar um comercial onde um policial esteja correndo entre as vielas de uma favela, usando um tênis de corrida de ultima geração, comece a trocar tiros com os 
chamados traficantes e ao final do anúncio, ao invés da chamada "Nike, just do $i t$ " temos "bandido bom é bandido morto". Essa nova forma de agir do poder punitivo que se instala em busca do inimigo é

[...] pobre, funciona porque é pouco inteligente, é elementar, não pensa e promove uma greve do pensamento ou pensamento nulo, porque explodiria ao menor sopro do pensamento. $\mathrm{O}$ exercício do poder punitivo tornou-se tão irracional que não tolera sequer um discurso acadêmico rasteiro, ou seja, ele não tem discurso, pois se reduz a uma mera publicidade. ${ }^{10}$

Assim se resume o atual discurso penal do inimigo. No que se refere ao conteúdo, é infinitamente menos elaborado do que em suas versões anteriores, no entanto, em relação à sua propagação, parece ser - também por causa da globalização, mídia, redes sociais - muito mais efetivo. Vemos que sua versão de hoje, contudo, é, talvez, a mais próxima de sua origem romana, em que o hostis era exatamente aquele que vem de fora ou aquele apontado pelo poder instituído como tal por ter se mostrado perigoso à sociedade.

\footnotetext{
${ }^{10}$ Ibid. p, 77.
} 


\section{CAPÍTULO 2 - DIREITO PENAL DO INIMIGO EM GÜNTHER JAKOBS.}

Em se tratando do tema proposto nesse trabalho, falar de Direito Penal do inimigo sem ao menos mencionar a contribuição de Günther Jakobs seria, no mínimo, desonesto. O professor da Universidade de Bonn ficou muito conhecido por tratar especificamente desse tema e suas ideias têm atraído atenção de toda parte da academia que se debruça sobre Direito Penal e Criminologia. Por óbvio, o objetivo aqui não será esmiuçar todo o pensamento desse jurista, o que por si só já poderia ser objeto de um trabalho completo, mas apresentar as linhas principais da produção desse autor e fazer alguns comentários a respeito da teoria para que possamos avançar.

Inicialmente, é oportuno salientar que, como já demonstrado no capítulo acima, Jakobs de forma alguma cria a figura do inimigo. Na realidade, talvez grande parte do espanto e curiosidade que seu trabalho desperta seja devido ao fato de que o professor se utiliza dos termos "inimigo" e "não-pessoa". Dessa forma, fala com sinceridade e sem rodeios linguísticos sobre aquilo que as teorias legitimadoras da pena e do Direito Penal como um todo sempre fizeram tentando dar uma roupagem que obscurecesse o conteúdo ontológico dos discursos. Ao mesmo tempo, seu trabalho surge contextualizado em um cenário mundial onde a intervenção dos Estados Unidos em países, principalmente do Oriente Médio, se dá de forma mais visível e difundida pela mídia devido aos acontecimentos de 11 de setembro de 2001 sob o pretexto de defesa nacional frente a um inimigo que não conhece fronteiras. Dessa forma, o discurso midiático e a política criminal de expansão do poder punitivo ganham um alicerce acadêmico no qual se agarrar. 
Um segundo esclarecimento prévio do pensamento de Jakobs é que sua ideia é precisamente de contenção do poder punitivo do Estado. O que o autor pretende é exatamente separar o Direito Penal do inimigo do Direito Penal do cidadão, para que se possa controlar o avanço do poder punitivo através desses dois compartimentos estanques que, separados, na visão de Jakobs, podem ser controlados, mas, ao serem entrelaçados como são atualmente, acabam sendo perpetradores de violações aos direitos individuais das pessoas.

O primeiro passo para entender o pensamento de Jakobs é perceber que o autor entende que o fim do Estado é garantir a vigência do ordenamento jurídico que, por sua vez, torna possível a liberdade. ${ }^{11}$ Dentro desse entendimento, Jakobs faz uma descrição do Direito. Para ele, o Direito Penal do inimigo e o Direito Penal existem, porém estão emaranhados dentro dos ordenamentos jurídicos. Ou seja, o autor não pretende criar uma noção de Direito Penal do inimigo e, consequentemente, um espaço de regulamentação do mesmo. Para ele, esse sistema já se encontra na realidade jurídica dos ordenamentos positivos.

Jakobs entende o Direito Penal como uma defesa da norma. Qualquer violação de uma norma é uma violação do ordenamento como um todo. Nesse sentido, a pena tem algo de simbólico, ou seja, a pena significa algo. No caso, para ele, a pena significa uma resposta ao fato. ${ }^{12}$ Enquanto sujeito capaz e assim considerado como pessoa, o autor do fato pretende, segundo Jakobs, desautorizar a norma a partir de seu ato e assim dizer que aquela norma não é

\footnotetext{
${ }^{11}$ JAKOBS, Günther. e MELIÁ, Cancio. Direito penal do inimigo: noções e críticas. Porto Alegre: Livraria do Advogado, 2012. p, 39.

${ }^{12}$ Ibid. p, 18 ss.
} 
válida. Nesse cenário, a pena surge como uma resposta ao autor dizendo que sua ação é irrelevante e o ordenamento continua valendo, apesar de sua desobediência. Dessa forma, a sociedade permanece intacta. Essa comunicação só é possível no Direito Penal uma vez que o autor é considerado um sujeito capaz e, portanto, considerado como pessoa.

Por outro lado, o que vai definir o tratamento do indivíduo como inimigo ou não é a noção de ente perigoso. Aqui, não há mais comunicação. Ao ente perigoso não se aplica uma pena após um fato delituoso, mas sim uma medida de segurança, uma medida física para que se impeça um mal provável a partir da noção de periculosidade do agente. Nesse sentido, há, aqui, o adiantamento da punibilidade e o Direito Penal deixa de se basear em fatos passados para se preocupar com fatos futuros. No entanto, para que essa medida se imponha, é necessário que a esse indivíduo não seja reconhecido ou que lhe seja retirado o status de cidadão. Podemos dizer que Jakobs é um iluminista tardio que concorda com a construção hobbesiana do contrato social, onde nem todos os delinquentes eram considerados inimigos, mas somente aqueles que poderiam ser perigosos para o contrato, como por exemplo, os que cometem crime de alta traição ou persistem na reiteração de crimes. Isso acontece no caso da figura que hoje temos do terrorista - em um plano internacional - e no caso dos traficantes de drogas - no plano latino americano. Os indivíduos assim denominados rechaçam o Estado e suas normas por princípios e querem, consequentemente, destruir esse Estado entendido como ordem jurídica.

Um segundo problema abordado pelo professor é o de que os atos praticados pelos inimigos são também delitos previstos em qualquer 
ordenamento. Seus atos são, em geral, tipificados como crimes que podem ser perpetrados por qualquer cidadão ordinário ao qual se dirige o Direito Penal do cidadão. Nesse caso, tratar o inimigo com as mesmas regras do Direito Penal do cidadão passa a ser algo inadequado, uma vez que o inimigo não corresponde às expectativas de uma conduta atribuída aos cidadãos. Ao tratar o inimigo como pessoa, o Estado se mostra ineficaz e põe em perigo o resto da sociedade. Ao mesmo tempo, ao tratar o inimigo a partir de sua periculosidade dentro do Direito Penal do cidadão, o Estado passa a sobrepor as medidas de segurança às garantias, tratando muitas vezes os cidadãos como inimigos. É essa confusão causada pelo entrelaçamento dos dois sistemas que Jakobs pretende resolver. Em suas palavras:

Quem não quer privar o Direito Penal do cidadão de suas qualidades vinculadas à noção de Estado de Direito - controle das paixões; reação exclusivamente frente a atos exteriorizados, não frente a meros atos preparatórios, a respeito da personalidade do delinquente no processo penal, etc. - deveria chamar de outra coisa aquilo que tem que ser feito contra os terroristas, se não se quer sucumbir, isto é, deveria chamar Direito Penal do inimigo, guerra contida. ${ }^{13}$

Podemos perceber que Jakobs descreve uma situação que existe nos ordenamentos jurídicos de hoje, qual seja, o entrelaçamento e confusão de Direito Penal do inimigo e Direito Penal do cidadão. Logo após, passa para uma parte prescritiva, ou seja, parte do pressuposto de que esse Direito Penal do inimigo não só é, como deve ser, mas que a maneira como os ordenamentos atuais regulam o mesmo é que está equivocada. Para ele, o fato de se emaranharem ambos os sistemas é que pode trazer problemas para a configuração da sociedade. Sendo assim, podemos entender que o que Jakobs defende não é a expansão do poder punitivo do Estado, nem tão pouco a

\footnotetext{
${ }^{13}$ Ibid. p, 26.
} 
criação de um novo Direito Penal. O que podemos perceber, na verdade, é que sua intenção é justamente a de conter o poder punitivo do Estado ao separar dois sistemas ou dois discursos que, no momento, se sobrepõe um ao outro e que, ora é danoso à sociedade por tratar os cidadãos como entes perigosos ao invés de tratá-los sob a égide da contradição que a pena propõe para reafirmação da norma infringida, ora trata os inimigos como pessoas, concedendo-lhes todas as garantias que deveriam estar restritas aos cidadãos, ignorando a periculosidade que esses indivíduos trazem consigo e, dessa forma, sendo ineficaz para proteger a sociedade. Essa vontade de contenção se dá pela verificação de que o Direito Penal, mais precisamente o poder punitivo do Estado, tem se expandido de forma vertiginosa nas ultimas décadas.

Dado o rebuliço que se instalou devido à produção acadêmica de Günther Jakobs, não faltaram vozes que tenham se levantado para apoiar ou criticar o trabalho do professor da Universidade de Bonn. Com efeito, o que aqueles que discordam tendem a concordar é que sua formulação do Direito Penal do inimigo acaba por não estabilizar as normas como pretendido, mas apenas segregar grupos de pessoa que em geral são vítimas de intolerância e preconceito dentro das suas respectivas sociedades. Ao mesmo tempo, o Direito Penal do inimigo deixa de se voltar para o fato e se volta para a figura de um autor ou potencial autor específico, passando a ser Direito Penal do autor.

Uma das vozes que debate com Jakobs a concepção de Direito Penal do inimigo de forma crítica é a de Manuel Cancio Meliá, professor da Universidad Autónoma de Madrid. Para ele, um dos problemas da formulação desse Direito Penal do inimigo é a pressuposição errônea de que os riscos que o inimigo é 
capaz de gerar para a sociedade são dados fáticos da natureza e não uma construção social que em nada corresponde à realidade fática. Em outras palavras, para Meliá, o inimigo não é perigoso ou tão perigoso como se propõe. Na verdade, para o professor, nem mesmo as ações que são abarcadas pelo Direito Penal do inimigo seriam situações que expõem a sociedade como um todo ao perigo de seu desmantelamento. ${ }^{14}$

Ao mesmo tempo, há que se notar como o Direito Penal do inimigo se mostra contraditório do sentido da teoria da pena. Uma vez que Jakobs concebe a pena como contradição a partir da qual o autor do delito desafia a norma e a pena serve como reafirmação da validade desta, desautorizando o autor e retificando o ordenamento, quando passamos a permitir a figura do inimigo, estamos, ao mesmo tempo, dizendo que sua capacidade de questionamento da norma é tão grande que se faz necessário tirar do mesmo o status de cidadão, ou seja, de destinatário da norma, para que se possa contê-lo ou eliminá-lo. Ora, se o Estado é quem tem o poder de decidir quem é cidadão através da atribuição de um status, ao retirar ou negar esse status ao inimigo, o Estado admite sua derrota e consequentemente reconhece a fragilidade de seu ordenamento pelo simples fato de tratar alguém como uma "não-pessoa".

Uma segunda voz que se manifesta contra o Direito Penal do inimigo proposto por Jakobs é a do professor da Universidade de Buenos Aires e exministro da suprema corte argentina, Eugênio Raúl Zaffaroni. Para ele, a tese

\footnotetext{
${ }^{14}$ Ibid. p, 54 ss.
} 
de Jakobs, apesar de bem intencionada, é ingênua, pois não percebe que "o conceito jurídico de inimigo só é admissível em um Estado absoluto."15

Para o professor argentino, o que seu colega alemão não percebe é que não há como se impor limites à despersonalização do agente perigoso, porque quem define a periculosidade do agente e, por consequência, seu grau e extensão, é sempre aquele que detém esse poder. Como é impossível prever ações futuras, essa incerteza mantém o poder de arbítrio do individualizador até que este último decida pela não periculosidade do agente. Um exemplo nítido desse processo são os prisioneiros da prisão americana em Cuba, que leva o nome de Guantánamo.

Outro ponto criticado em Jakobs é que o mesmo invoca, em casos excepcionais, a necessidade como uma causa legítima para que o Estado de Direito proteja a sociedade. No entanto, ao invocar a necessidade, é de se deduzir que alguém terá de julgar essa situação e Jakobs concebe o julgamento ao próprio soberano. Nesse caso, ao invocar a necessidade como emergência o Estado pode - e vemos na realidade que faz - suspender sua proteção aos cidadãos por tê-los como inimigos. Uma prova disso é que no Brasil, por exemplo, quase metade de todas as pessoas que se encontram encarceradas estão presas preventivamente, ou seja, estão presas em um caráter de periculosidade por algo que podem vir a fazer ao invés de uma pena que visa um fato pretérito.

\footnotetext{
${ }^{15}$ ZAFFARONI, Raúl Eugênio. O inimigo no direito penal. Rio de Janeiro: Revan, 2007. p, 160.
} 
Enfim, após o breve esboço da teoria de Günther Jakobs e com as críticas ao cerne do pensamento desse autor, podemos perceber que, assim como grande parte dos penalistas hoje, a proposta de Jakobs é a de conter o avanço do poder punitivo do Estado. Ao mesmo tempo, vimos que é verdade que nosso Direito Penal mistura elementos de um Estado de direito que lida com aquele que infringe a norma de maneira a considerar seu status de pessoa a partir da contradição e, ao mesmo tempo, tem elementos de um Estado absoluto que lida com os indivíduos seletivamente de forma a despersonalizálos, tratando-os como "não-pessoas" no sentido de sua periculosidade. O problema não está, porém, como pretende o professor alemão, em separar ambos os sistemas em compartimentos isolados para que se controle o avanço do poder punitivo, mas sim em admitir que dentro do Estado de Direito possa existir a concepção de inimigo. Enquanto essa concepção for aceita e legitimada, estaremos sempre, inexoravelmente, caminhando rumo ao Estado absoluto.

Finalmente, depois do breve caminhar histórico mostrando a origem e desenvolvimento do inimigo durante seus períodos de mudança de discurso mais significativos e após uma breve exposição do debate contemporâneo mais relevante sobre o tema no âmbito teórico, podemos passar ao exame das implicações da noção de inimigo na política criminal e na dinâmica da segurança pública da cidade do Rio de Janeiro a partir dos anos 90. 


\section{CAPÍTULO 3 - OS INIMIGOS DO RIO DE JANEIRO.}

\section{1 - CRIMINALIZAÇÃO SECUNDÁRIA.}

Todo Estado moderno define e tipifica uma série de condutas que julga lesivas a bens jurídicos importantes. Essa tipificação consiste em criar uma lei penal incriminando essas condutas e permitindo a punição de seus autores. Esse processo se dá pelo poder político, mais especificamente no caso brasileiro através do poder legislativo, que cria essas leis de caráter abstrato e geral supondo que aqueles que incorrem nas condutas tipificadas devem ser processados e, ao fim, apenados pelo cometimento do crime. A essa etapa do processo de criminalização damos o nome de "criminalização primária". Esse programa acaba sendo tão geral e abstrato que seria impossível, além de indesejado, que fosse cumprido por completo. Isso acontece, primeiramente, porque é impossível que o Estado e seus agentes estejam a todo o momento em todos os lugares como um ente oniciente. Em segundo lugar, porque, mesmo que tivesse o Estado a ciência de todos os crimes que ocorrem na sociedade, seria o mesmo incapaz de perseguir todos eles. À parcela da criminalidade não conhecida pelo Estado, a criminologia deu o nome de "cifra oculta". Por essa razão, é normal que o sistema penal acabe tendo que selecionar apenas uma parte do programa da criminalização primária para ser realizado em um segundo momento.

À segunda etapa do processo de criminalização, damos o nome de “criminalização secundária”. Diferentemente da criminalização primária que é uma abstração geral quanto ao desvalor de uma conduta, a criminalização 
secundária é a "ação punitiva exercida sobre as pessoas concretas." ${ }^{\text {"16 }}$ Os atores dessa segunda etapa não são aqueles que produzem a norma em abstrato, mas aqueles que executam sua prescrição normativa, na maioria das vezes, portanto, as agências policiais.

Grande parte dos indivíduos aprisionados está presa, pois seus delitos não requerem maior complexidade de investigação por parte das agências policiais. Em geral, são crimes contra o patrimônio cometidos à luz do dia, em locais públicos e executados de forma grosseira ou o varejo do tráfico de drogas. O que a comunicação social mostra à sociedade são exatamente esses indivíduos presos, que correspondem a essa parcela das pessoas que cometem os delitos mais grosseiros e, ao mesmo tempo, acaba escondendo aqueles que comentem crimes mais sofisticados que pressupõe uma educação menos primitiva. Desse fato se desenrola a errônea conclusão da sociedade de que a delinquência se restringe às camadas mais pobres e marginalizadas da população, reforçando preconceitos e culminando em outra conclusão equivocada: a de que a pobreza e falta de educação sejam as causas da criminalidade. A verdade é que esses fatores não correspondem às causas da criminalidade, porém condicionam os tipos e formas de ilícitos desse segmento da população e sua criminalização que, por sua vez, é de mais fácil repressão por parte das agências policiais.

Ao mesmo tempo, seria muito ingênuo da parte de qualquer pessoa achar que essa seleção que acontece na criminalização secundária está protegida ou desvinculada de outras agências que atuam na sociedade como a

\footnotetext{
${ }^{16}$ ZAFFARONI, Eugenio Raúl e BATISTA, Nilo. Direito penal brasileiro. Primeiro volume. Rio de Janeiro: Revan, 2003. p, 43.
} 
mídia, agências políticas, atores econômicos etc. Aquela parcela da população com menos poder político, com menos voz, sem acesso positivo à comunicação social, marginalizada e, consequentemente, mais vulnerável, é destinatária de um estereótipo de delinquente que é criado pela imaginação coletiva através dos agentes da sociedade que depositam sobre essa população toda uma carga valorativa negativa sob a forma de preconceito. Esse, por sua vez, induz o senso comum coletivo a atribuir uma carga estética negativa a tudo aquilo que se apresenta como ruim, perigoso ou indesejado, despertando um sentimento de ojeriza aos destinatários dos preconceitos. Isso se dá pelo fato de que nossa noção da realidade é um dado construído através da nossa apreensão parcial e seletiva dos eventos que nos são apresentados diuturnamente. É essa nossa noção que vai definir para nós o que é real. Nesse sentido, Lola Aniyar de Castro é precisa ao dizer que "o sentimento de insegurança é socialmente construído e, por isso, é seletivo." ${ }^{17} \mathrm{O}$ sentimento de insegurança presente na sociedade não é algo dado, mas sim construído. Ao construir um estereótipo de quem se deve temer como um representante de uma única classe vulnerável faz-se com que esse sentimento se amplie por ser direcionado a toda essa classe. Sendo assim, a criminalização secundária acaba se transformando em uma seletividade guiada que atua sobre a parcela mais vulnerável da sociedade, reforçando os preconceitos historicamente construídos e servindo para manutenção da desigualdade social, não raramente intensificando um processo de criminalização da pobreza e do racismo.

O estereótipo acaba sendo o principal critério seletivo da criminalização secundária; daí a existência de uniformidades da população penitenciária associadas a

\footnotetext{
${ }^{17}$ CASTRO, Lola Aniyar de. Criminologia da libertação. Rio de Janeiro: Revan, 2005. p, 210.
} 
desvalores estéticos (pessoas feias), que o biologismo criminológico considerou causas do delito quando, na realidade, eram causas da criminalização. ${ }^{18}$

Não podemos entender a criminalização secundária na América Latina e, consequentemente no Rio de Janeiro, dissociada do fenômeno da policização. Esse processo consiste em selecionar, treinar e condicionar aqueles que integram as agências policiais, responsáveis, em grande parte, pela realização da criminalização secundária. Historicamente, as agências policiais foram estruturadas de forma vertical e autoritária, afastando qualquer discussão interna sobre alocação de recursos e suas prioridades. Os operadores da base acabam sempre com salários que mal conseguem suprir suas necessidades básicas e, por isso, recorrem muitas vezes a atividades ilícitas para complementar sua renda. Ademais, são precisamente os operadores das agências policiais que estão na base que correm os maiores riscos de vida no trabalho. Por fim, a regra é que esses operadores sejam oriundos das mesmas camadas sociais em que a criminalização secundária incide. Assim, os preconceitos e os valores negativos atribuídos às classes subalternas passam a incidir também sobre os policiais que acabam sendo generalizados como corruptos, desonestos e violentos. Ou seja, o estereótipo de policial também se encontra recheado de racismo e preconceitos assim como o estereótipo criminal.

Por último, temos o fato de que a mídia mostra e os atores políticos da segurança pública abordam o fenômeno da criminalidade sempre como uma forma de guerra. São soldados mortos caídos, inimigos executados, operações policiais como missão, pacificação de áreas controladas, retomada de território

\footnotetext{
${ }^{18}$ ZAFFARONI, Eugenio Raúl e BATISTA, Nilo. Direito penal brasileiro. Primeiro volume. Rio de Janeiro: Revan, 2003. p, 46.
} 
etc. Se a criminalização secundária atua de forma discriminatória na população mais vulnerável e os operadores das agências policiais são recrutados dessa mesma camada da sociedade, temos que essa "guerra" acontece afligindo exatamente a parte mais vulnerável da sociedade. Essa abordagem bélica acaba potencializando medos e preconceitos, que por sua vez passam a relativizar os direitos humanos, passando a ver os mesmos sempre como um obstáculo em contraposição à segurança, impedindo que sejam propostos modelos alternativos para solução de conflitos e pondo os críticos do sistema sempre como coniventes ou defensores da violência. Por isso, entender a dinâmica do poder punitivo através da criminalização secundária e da policização gerando um estado de guerra é essencial para compreender como se dá a política de segurança pública no Rio de Janeiro e como ela faz parte de uma política criminal do inimigo.

\section{2 - OS TRAFICANTES.}

O inimigo público número um do Rio de Janeiro são os chamados "traficantes de drogas". Para fins da Lei 11.343 de 2006, que prevê o tipo penal do tráfico ilícito de entorpecentes, traficante seria toda pessoa que importa, exporta, remete, prepara, produz, fabrica, adquiri, vende, expõe à venda, oferece, tem em depósito, transporta, traz consigo, guarda, prescreve, ministra, entrega a consumo ou fornece drogas, ainda que gratuitamente, sem autorização ou em desacordo com determinação legal ou regulamentar como prescreve o artigo 33 da Lei. A pena pelo tráfico de drogas vai de 5 a 15 anos e o mesmo é equiparado a crime hediondo por força da Lei 8.072 de 1990, o que faz com que o mesmo seja insuscetível de anistia, graça, indulto ou fiança, além de ter uma progressão de regime mais grave, assim como passível de 
todas as outras medidas atribuídas aos crimes hediondos. Por fim, o comprovado envolvimento em tráfico ilícito de entorpecentes e drogas afins é motivo para extradição até mesmo de brasileiros naturalizados como exceção do inciso LI do artigo $5^{\circ}$ da Constituição que trata dos direitos e garantias fundamentais.

A verdade é que o que aparece nas leis e até mesmo na Constituição não é mais do que a consequência da imagem social dos traficantes. Embora a lei não possa dar um rosto para os traficantes, a mídia e o imaginário social podem. Essa imagem se materializa em jovens, negros, moradores de favelas, armados até os dentes, violentos, imorais, bárbaros sem piedade, cheios de ódio no coração, sádicos, imprevisíveis, vingativos e, acima de tudo, perigosos. São seres que perderam a sua humanidade, são a personificação do mal e, como este faz parte de sua essência, estão além de qualquer salvação, sendo, portanto, incorrigíveis.

A imagem dos traficantes, além de vendedores de drogas, está intrinsecamente ligada com a imagem de alguém que comete roubo, homicídio, latrocínio, lesão corporal, tortura e tantos outros crimes que, de maneira cruel e bárbara, transformam a cidade em um lugar violento e faz com que todos se sintam inseguros em qualquer lugar a qualquer hora. Daí fica fácil entender o porquê das consequências penais para o tráfico de drogas serem tão severas. Essas normas não estão voltadas para o ato de traficar, mas para os traficantes e, através da criminalização secundária, transformam o Direito Penal do fato em verdadeiro Direito Penal do autor. Não estão preocupadas com o ato que se passou, mas com o indivíduo que pretendem neutralizar e sua periculosidade. 
Esse fenômeno, no entanto, não é aleatório, mas é consequência necessária e funcional da sociedade pós-industrial de consumo. Não é a toa que, além dos atributos psíquicos subjetivos dos traficantes no imaginário social, sejam também eles jovens, negros, moradores de favelas ou subúrbios do Rio de Janeiro. É que essas pessoas são, ao mesmo tempo, aqueles que não se enquadram na sociedade de consumo. A pobreza não tem espaço nessa nova configuração da sociedade e precisa ser neutralizada. No caso do Rio de Janeiro, essa neutralização se dá por sua criminalização e, através da "guerra às drogas", identifica seus alvos como os varejistas, vendedores de rua, em sua maioria, jovens pobres que não são absorvidos pelo mercado de trabalho e encontram na venda de drogas sua única possibilidade de emprego. Em outras palavras, aqueles que não tem nada a oferecer para a sociedade uma vez que não tem poder de consumo devem ser, portanto, descartados.

Num mercado totalmente organizado em torno da procura do consumidor e numa sociedade interessada em manter essa procura permanentemente insatisfeita, os consumidores falhos são os novos impuros, já que o novo critério de pureza, ou de reordenamento, é a aptidão e capacidade de consumo. Esta nova ordem traz estratégias de privação e de desregulamentação junto "à preservação da pureza da vida consumista", produzindo exigências de incremento das liberdades do consumidor e, por outro, o discurso de "lei e ordem" para as vítimas do processo de privatização e desregulamentação, os consumidores falhos. "o ideal de pureza da pós-modernidade passa pela criminalização dos problemas sociais."19

A ideia de que os traficantes sejam esses seres desalmados é útil para a nova lógica da sociedade de consumo, mesmo que não corresponda sequer à realidade do sistema prisional relativo ao tráfico.

\footnotetext{
${ }^{19}$ BATISTA, Vera Malaguti. O medo na cidade do Rio de Janeiro. Rio de Janeiro: Revan, 2003. p, 79
} 
Enquanto a imensa maioria de traficantes desarmados e não violentos são encarcerados, os veículos de comunicação justificam as ações do sistema penal através do chamado "combate à violência". Cria-se assim uma verdadeira presunção de violência, sem previsão legal, para aqueles autuados no tráfico de drogas. ${ }^{20}$

Percebemos que o traficante que é preso não passa de mero varejista, aquele encontrado com pequenas quantidades, e que, muitas vezes, sequer está armado configurando uma ameaça real. Nota-se, no entanto, que a mesma carga valorativa negativa e ânsia repressiva não atingem os grandes produtores e comerciantes de drogas que deslocam, por exemplo, centenas de quilos de drogas em helicópteros e aviões particulares ou outras formas de esconder o produto. É apenas sobre o varejista considerado um "ser perigoso" e "inimigo" que recai o rótulo de traficante, além de toda a culpa pela violência e caos da cidade.

A política genocida de "guerra às drogas" só faz algum sentido quando entendida nessa lógica de criminalização da pobreza e de controle e extermínio das classes pobres. Não há outra conclusão plausível quando a sociedade permite o uso, porém condena o comércio. Fora dessa compreensão de que a "guerra às drogas" serve apenas para criminalizar uma parcela específica da população, não há lógica alguma em um contrato onde a compra é lícita e a venda é ilícita. Esse movimento se mostra cristalino quando vemos que a Lei 11.343/06 abrandou a pena do porte de drogas para uso pessoal, sendo o crime previsto no artigo 28 da mesma Lei alterado para regime menos gravoso sujeito a aplicação da Lei 9.099/95 (Lei dos juizados especiais), ao mesmo tempo em que aumentou a pena mínima do seu artigo 33 para cinco anos, fazendo com que se impossibilite a conversão em penas restritivas de direito.

\footnotetext{
${ }^{20}$ ZACCONE, Orlando. Acionistas do nada: Quem são os traficantes de drogas. Rio de Janeiro: Revan, 2011. p, 119.
} 
Atualmente está sendo julgado o Recurso Extraordinário 635.659. O mesmo traz a tese - que parece que será acatada pelo Supremo Tribunal Federal - de que o artigo 28 da Lei 11.343 é inconstitucional. Caso seja esse o desfecho do julgamento, estará coroada uma ideologia de diferenciação. Os jovens das classes abastadas serão usuários recreativos eventuais ou dependentes químicos que precisam de tratamento e os jovens pobres que vivem do comércio varejista das substâncias psicoativas serão alvos do poder punitivo Estatal.

Com isso, fica claro que o discurso moralista sobre as drogas e seu caráter ofensivo à saúde nada mais é do que uma cortina de fumaça para controlar a parcela da população tida como perigosa.

A cocaína - a droga neoliberal, símbolo do êxito e de status entre seus consumidores (yuppies high-tech, jovens empresários, executivos de bolsas de valores) - tem como contrapartida a destruição da juventude pobre das nossas favelas, lançadas pelas leis do mercado à criminalização e ao círculo viciado da violência urbana. ${ }^{21}$

O medo generalizado difundido através do bombardeamento diário de notícias sensacionalistas - que mais parecem uma sessão de lavagem cerebral -, a larga quantidade de programas televisivos que se resumem em ficar noticiando crimes com apresentadores que são verdadeiros marqueteiros da tragédia e a espetacularização da violência policial enaltecida por políticos, setores conservadores da sociedade, produções cinematográficas e por gurus do horário nobre, conseguem criar uma verdadeira atmosfera de pânico que é

\footnotetext{
${ }^{21}$ BATISTA, Vera Malaguti. Dificeis ganhos fáceis: Drogas e juventude pobre no Rio de Janeiro. Rio de Janeiro: Revan, 2003. p, 101.
} 
usada para que se legitime qualquer intervenção contra esse "ser do mal" que se projeta na figura dos traficantes de droga.

Não é raro que, em qualquer discussão sobre violência e segurança pública, alguém enalteça a máxima “bandido bom é bandido morto". Quando vamos analisar essa ideia mais de perto, percebemos que o "bandido" não pode ser traduzido em criminoso abstrato, ou seja, qualquer um que cometa um crime. A noção de bandido entendida dentro desse contexto se limita à criminalidade mais grosseira e, principalmente, cometida por quem possui as mesmas características objetivas dos traficantes de drogas. Ou seja, aqueles que são em geral jovens, negros, pobres, oriundos das favelas ou subúrbios, não raramente em situação de desemprego. Essas características não necessitam estar sempre somadas em todos os casos, mas podem ser combinadas de várias formas diferentes. É certo, no entanto, que a máxima incide mais intensamente em quanto mais dessas categorias o indivíduo estiver incluído.

Assim, se "como se sabe" a violência urbana tem como principal combustível o tráfico de drogas, sendo o traficante um jovem criminoso "empedernido e irrecuperável", para o qual parece "brincadeira de mau gosto falar de ressocialização", a única saída para reorganizar o caos passa a ser "novas prisões e novas leis". Convencendo-se assim a audiência e o próprio interlocutor de que poderemos diminuir significativamente a violência urbana enterrando todo o malestar decorrente da nossa liberdade consumista através do encarceramento dos "traficante", que passam a ocupar o espaço que outrora fora destinado a hereges, judeus e comunistas. ${ }^{22}$

\footnotetext{
${ }^{22}$ BATISTA, Vera Malaguti. O medo na cidade do Rio de Janeiro. Rio de Janeiro: Revan, 2003. p, 124.
} 
A política de guerra às drogas na verdade é guerra aos traficantes. Ninguém seria louco de entrar em guerra contra uma muda de cannabis ou contra uma a plantação de coca. Essa guerra usa do medo para legitimar um discurso punitivo que tenta sempre se expandir e, usando como razão principal o caráter emergencial das medidas para que a sociedade não seja mergulhada no caos ou "entregue aos bandidos", acaba escondendo seu objetivo funcional que realiza com maestria, qual seja, o controle social das classes perigosas através da criminalização da pobreza.

Nosso atual sistema incentiva violência, acentua desigualdades sociais, regionais, raciais, enriquece bandidos, extermina idealistas, coloca crianças no tráfico, tira dinheiro de universidades para construir prisões, custa caro, gera frustrações e ressentimento, esgarça o tecido social, corrói direitos, treina criminosos, aumenta o uso de drogas e as torna mais potentes e perigosas. ${ }^{23}$

\section{3 - POLÍTICA NEOLIBERAL DE DIREITOS HUMANOS.}

Nos anos oitenta tem início um novo modelo de ordem social de caráter conservador trazido pelo neoliberalismo. Esse modelo se contrapõe àquele do Estado de Bem-Estar Social, cujo paradigma era a segurança social, sendo um modelo baseado na desintegração social e principalmente na produção da sensação de insegurança e medo. Esse novo modelo se origina nos países ditos de primeiro mundo e se espalha pelo resto do globo se adaptando às realidades e características contingentes de cada país. A partir do novo modelo neoliberal podemos perceber diversas mudanças ao longo dos anos. Vemos que há um aumento significativo do desemprego e aumento do trabalho informal derivados da flexibilização das relações de trabalho. Além disso, a exclusão

\footnotetext{
${ }^{23}$ Ibid. p, 54.
} 
social se agrava, pois, anteriormente, a mesma se dava por fenômenos contingentes gerados pelas crises que o sistema capitalista necessita para se reciclar. Essa exclusão, porém, passa a ser estrutural, o que impede grande parte dos trabalhadores de serem reinseridos no mercado. A exclusão social também passa a ser geográfica. Constroem-se áreas privadas e impenetráveis, verdadeiras fortalezas em formas de bairros que possuem sua própria segurança. Por fim, esse novo modelo neoliberal acaba por mercantilizar as profissões e carreiras dissolvendo as identidades que formavam ou faziam mais fortes os laços sociais.

O que antes eram questões de saúde pública, de seguridade social e de inclusão social passou a ser visto como questão criminal. O objeto de todas as preocupações passa a ser o mercado e a economia passa a ser a nova teoria social para resolução dos problemas, uma vez que é tida como neutra e objetiva, além de alegadamente possuir as respostas para todos os conflitos. Dessa forma, como o Estado deixa de ser aquele que se preocupa com a segurança social, esse espaço passa agora a ser delegado ao Direito Penal.

O estado abandona o seu papel de composição e arbitragem, passando para o mercado a regulação social. A ciência econômica passa a ser o centro da teoria social como um saber indiscutível e inquestionável, supostamente neutro e absolutamente objetivo, buscando legitimar a nova realidade. Na verdade, as práticas adotadas não passam de decisões políticas marcadas por interesses das classes detentoras do poder econômico. $^{24}$

No Brasil, podemos verificar que as ações de vigilância e repressão se concentram exatamente nas classes sociais mais vulneráveis. Sobre os pobres é

\footnotetext{
${ }^{24}$ DORNELLES, João Ricardo W. Conflito e Segurança: Entre pombos e falcões. Rio de Janeiro: Lumen Juris, 2008. p, 27.
} 
que recaem os instrumentos de controle social mais gravosos do Direito Penal. As respostas de caráter conservador e antidemocrático do Estado tentam resolver os problemas da segurança pública através da militarização das polícias e seu treinamento bélico, com maior efetivo e com maior poder de fogo para que possam ter mais força no combate ao crime como se estivessem combatendo em uma guerra. Junto a isso, temos que os programas de lei e ordem reproduzem um discurso de cunho moralista que tenta, através do medo e pânico, rotular os traficantes de drogas, assim como usuários das drogas, nos verdadeiros problemas da sociedade e fonte de toda criminalidade. Fácil perceber isso depois do lançamento do filme Tropa de Elite, em que sessões de tortura e de constrangimento moral realizados pelos policias durante o filme foram aclamados pelo público e até deram origem a bordões que podiam ser ouvidos diariamente. O que isso acaba gerando, na prática, é um aumento de mortes decorrentes dessa política de guerra às drogas e de combate à criminalidade, além do aumento da população carcerária. Por fim, esse aumento do sistema penitenciário acaba por atrair os olhares da privatização, que vê nesse sistema uma fonte de lucro e promove seus interesses financeiros sob um hipócrita argumento de dignidade humana.

Todo esse discurso de lei e ordem e combate à criminalidade - essa tida somente como criminalidade de rua - acaba por desumanizar os delinquentes. Esse discurso legitima e constrói um Direito Penal de emergência que criminaliza condutas, encarcera mais e promove uma verdadeira desestruturação social que só consegue segregar mais ainda as classes. Essa desumanização, que acaba sendo um pressuposto do neoliberalismo, é fundamental para o Direito Penal do inimigo, uma vez que ao se construir a ideia de que alguns indivíduos não carregam o status de pessoa e, sendo esses os excluídos da sociedade de consumo, legitima-se o extermínio dos mesmos. 
É necessário, portanto, entender que a política criminal faz parte da política social e, sendo assim, também deve ser vista como integrante de um sistema de controle social. A partir dessa ótica, devemos entender que a política criminal neoliberal se insere em um momento onde os interesses dos grandes atores econômicos e do Estado se confundem. Ademais, é um modelo de política criminal que visa principalmente a criminalidade visível em lugares públicos e grosseira. Em outras palavras, aquela que se dirige à criminalidade de rua, praticada pela parcela mais vulnerável e excluída da sociedade de consumo. Além disso, esse modelo se preocupa com o seu eficientismo e se agarra em uma política de resultados. Isso se dá porque visa, principalmente, se dirigir contra classes "perigosas" que realizam a desordem social. Logo, trata todos aqueles que pertencem a essa classe como potenciais delinquentes e dignos apenas de suspeita e repressão. Desse modo, deixa de lado políticas inclusivas para que se ponham em prática modelos excludentes baseados no instrumento penal.

A opinião publicada e a mídia acabam restringindo a noção de crimes para aqueles cometidos à luz do dia, de maneira grosseira e por pessoas sem maior educação para transgredir de forma mais sofisticada. Assim, se alastra o preconceito e a falsa ideia de que a criminalidade é exclusiva das classes pobres e reforça os estigmas do delinquente e da vítima, sendo o primeiro sempre alguém das classes marginalizadas e o segundo, sempre um "cidadão de bem”. Essas pessoas suspeitas é que devem ser monitoradas, vigiadas e controladas para que os "cidadãos de bem" possam ter paz e tranquilidade no seu dia a dia. 
Essa maneira de se conceber um direito penal de emergência e que lida com as questões sociais criminalizando-as com fundamento em discurso de lei e ordem é conhecida como eficientismo penal: trata as questões sociais de uma forma fundamentalista e tem a ilusão de que o Direito Penal seria capaz de resolver os conflitos sociais. Ademais, essa concepção do Direito é diametralmente oposta à noção constitucional do Direito Penal. Como busca a celeridade na resolução dos conflitos através do Direito Penal de emergência, o eficientismo ignora as garantias mais básicas materiais e processuais dos cidadãos. É focado em uma lógica binária errônea e moralista de bem contra o mal, de delinquentes contra vítimas, de perigosos contra pessoas de bem. Em suma, do bem contra o mal. Seus resultados, no entanto, são, ironicamente, muito aquém das expectativas quando não mesmo aumentam a criminalidade. Isso ocorre porque, uma vez que precisa da emergência, esse sistema precisa sempre criá-la para que se mantenha e, ao mesmo tempo, quando efetiva suas práticas acaba por não solucionar os conflitos, quando muito, piorando-os. Além disso, por se focar somente em resultados, acaba por descontextualizar os conflitos sociais, examinando-os sob um aspecto restrito e técnico do Direito Penal que ignora formas mais complexas e dinâmicas da criminalidade como as organizações criminosas, a corrupção administrativa, e os "white colar crimes". Isso faz com que esses grupos de crimes e, por consequência, seus perpetradores não sejam punidos, aumentando a impunidade dessas classes. Logo, o aumento seletivo do sistema penal através do eficientismo acaba por excluir e estigmatizar ainda mais as classes pobres. Por causa desses resultados já mencionados é que o eficientismo se mostra oposto a todos os objetivos dos direitos humanos e dos princípios constitucionais democráticos.

Em oposição ao eficientismo, temos o Direito Penal mínimo. Este último é o único modelo de Direito Penal compatível com um programa 
constitucional que pretenda a inclusão social, diminuição e superação das diferenças sociais e respeito às garantias individuais. Esse Direito baseado em concepções iluministas, já em Beccaria, mostra a debilidade do eficientismo.

Falsa ideia de utilidade é a que sacrifica mil vantagens reais a um inconveniente imaginário ou sem grandes consequências; é a que tiraria o fogo dos homens, porque incendeia, e a água porque afoga, e que só reparta os males com a destruição. ${ }^{25}$

O Direito Penal Constitucional, hoje, tem o caráter iluminista de limitar o poder punitivo do Estado. Tarefa essa que, como visto acima, é algo já sabido há muito tempo. Nesse sentido é que Juarez Cirino dos Santos diz ficar impressionado quando uma corrente do Direito Penal, o garantismo - que nada mais é do que a efetivação dos ideais iluministas da época da Revolução Francesa -, é hoje entendida como algo progressista. São preocupantes a força e estratégias que o poder punitivo do Estado tem conseguido imprimir através do modelo de sociedade pós Estado de Bem-Estar Social e o quanto se regrediu em relação às garantias e direitos individuais através da política criminal neoliberal.

Por isso, entender que o Direito Penal Constitucional tem uma dimensão política que deve se traduzir em política de proteção dos direitos humanos - como limitação da pena e impedimento da expansão do poder punitivo gerado pelo modelo neoliberal - tem um caráter civilizatório. Entender todos como sujeitos de direitos e não como seres perigosos e

\footnotetext{
${ }^{25}$ BECCARIA, Cesare. Dos delitos e das penas. São Paulo: Martins Fontes, 2005. p, 128.
} 
suspeitos é essencial para cumprir a vontade constitucional de diminuição da desigualdade e efetivar a justiça.

\begin{abstract}
A noção de segurança da cidadania não se restringe à busca de proteção contra a criminalidade e os processos de criminalização. Ao contrário, com o garantismo há uma concepção ampliada de segurança cidadã que abrange todos os direitos - civis, políticos, econômicos, sociais culturais e ambientais. A noção de segurança incorpora a paz, os direitos da igualdade, da liberdade e da cidadania política, bens culturais, e de uma ética solidária. ${ }^{26}$
\end{abstract}

Isso significa, em outras palavras, perceber que, ao pôr em prática um programa de política criminal que tem em vista um Direito Penal Constitucional com o recuo do Direito Penal para solução dos conflitos, nasce a possibilidade de se trabalhar esses mesmos conflitos a partir de óticas distintas, interdisciplinares, mais complexas e elaboradas que serão realmente mais efetivas. Esse, então, se mostra o caminho que pode respeitar os direitos fundamentais e efetivar as prescrições constitucionais.

\title{
3.4 - POLÍTICA DE CONFRONTO.
}

\subsection{1 - O GOLPE NOS DIREITOS HUMANOS}

Os anos noventa se iniciam no Estado do Rio de Janeiro com o governo de Leonel Brizola. O respeito aos direitos humanos e a percepção de que a presença do Estado com serviços e políticas inclusivas são essenciais

\footnotetext{
${ }^{26}$ DORNELLES, João Ricardo W. Conflito e Segurança: Entre pombos e falcões. Rio de Janeiro: Lumen Juris, 2008. p, 53.
} 
para diminuir as diferenças historicamente construídas sempre foram uma marca característica do então governador. Dessa forma, um modelo que privilegia a prevenção de crimes ao invés de seu confronto direto passa a ser praticado no início da década.

Obviamente que essa maneira de pensar os conflitos sociais incomodava e ainda incomoda muito os setores da direita conservadora e antidemocrática. Os mesmos, influentes e detentores da grande mídia, de forma alguma ficariam calados enquanto uma forma de governo como a brizolista tentava se consolidar no Estado. Durante o mandato do governador Brizola, o crime de extorsão mediante sequestro passou a crescer no Estado e isso era tudo o que as vozes conservadoras queriam. Dessa forma, esse delito passou a ser usado para insuflar o discurso de aumento de criminalidade e legitimar as pautas conservadoras de combate ao inimigo. Os meios de comunicação manipulavam o noticiário de forma a criar um sentimento de medo e insegurança na população através das notícias de crimes. Esses meios de comunicação e mídia criam uma imagem reducionista da cidade a fim de remexer o sentimento das pessoas, criando uma imagem de cidade em guerra ou de um "faroeste carioca", causando uma ilusão de caos e de histeria coletiva. Esse é o cenário perfeito para a proliferação e a implementação do discurso de lei e ordem.

Eis que no ano de 1993, o Estado do Rio de Janeiro, assim como o resto do Brasil, fica chocado com duas tragédias que são conhecidas até hoje como chacina da Candelária ${ }^{27}$ e o massacre de Vigário Geral ${ }^{28}$. Esses

\footnotetext{
${ }^{27}$ Tarde da noite de 23 de julho de 1993 policiais a paisana, dentro de dois carros, pararam em frente à Igreja da Candelária. Em seguida, atiraram contra dezenas de moradores de rua que dormiam ao pé da
} 
acontecimentos tiveram uma repercussão muito grande em todo o país, mas acima de tudo abalaram os moradores do Rio de Janeiro de tal forma que, até mesmo a noção do imaginário social da cidade como um lugar descontraído, de alegria, festas, praias e onde mora uma população alegre e simpática foi abalada.

Esses fatos acabaram por botar em xeque as políticas de direitos humanos praticadas pelo Governo e, cada vez, mais o mesmo começou a ser alvo de ataques, acusado de ser pouco firme ao lidar com a violência e até mesmo de ser condescendente com os criminosos. O peso simbólico dos massacres ocorridos veio como um golpe certeiro na política de segurança pública e nas lideranças do governo Brizola-Nilo Batista. Em pouco tempo, a população, bêbada de sentimentos conservadores e antidemocráticos e ainda impressionada com os episódios que se deram, começa a esvaziar o apoio e confiança depositados no Governo.

É então que segmentos conservadores das instituições policiais, de importantes segmentos políticos e da mídia em geral começam a construir um discurso maniqueísta que polariza a política de respeitos aos direitos humanos

igreja. A maioria crianças e adolescentes. Um dos sobreviventes (Sandro Barbosa do Nascimento) viria a ficar muito conhecido, anos mais tarde, ao assaltar o ônibus 174 no bairro do Jardim Botânico, fazendo uma refém. Em uma ação desastrosa da polícia televisionada ao vivo em rede nacional, a refém morre e Sandro é assassinado por policiais já dentro da viatura.

${ }^{28} \mathrm{O}$ massacre ocorreu na favela que leva o mesmo nome, localizada na Zona Norte da cidade do Rio de Janeiro. Na madrugada do dia 29 de agosto de 1993, policiais militares integrantes de grupo de extermínio, encapuzados e armados, invadiram a favela e executaram moradores. A motivação teria sido a morte de outros quatro policiais. O caso chegou a ser julgado na Organização dos Estados Americanos (OEA) como crime contra os direitos humanos. 
e a redução e contenção da criminalidade. Passa-se a associar a criminalidade crescente, a desordem urbana e a falta de segurança diretamente com o discurso dos Direitos Humanos e das garantias constitucionais através da ideia de que os últimos é que seriam um empecilho para o sucesso da política de segurança e da redução da criminalidade. É assim que se começa a criar a noção de que os Direitos Humanos privilegiam e protegem a desordem, o banditismo e a criminalidade. Assim, a cidadania seria algo exclusivo dos "cidadãos de bem", aqueles que se comportam de maneira ordeira, de acordo com a moral e bons costumes, além, principalmente, de pagarem seus impostos. ${ }^{29}$

\subsection{2 - OPERAÇÃO RIO.}

Em 31 de outubro de 1994, o então governador Nilo Batista ${ }^{30}$ assinou um convênio com o presidente Itamar Franco para combater e reprimir tanto o tráfico de drogas como o tráfico de armas no Estado do Rio de Janeiro através de ações conjuntas da polícia com as forças armadas, em especial o exército. Esse convênio, que ficou conhecido como "Operação Rio", foi resultado das pressões que o governo vinha sofrendo por parte dos setores conservadores e antidemocráticos que defendiam o modelo de segurança baseado na lei e ordem. Em decorrência do clima de medo criado, do avanço do discurso punitivo e do enfraquecimento do discurso de direito humanos e garantias frente ao suposto caos urbano, o Governo do Estado se encontrava em posição

\footnotetext{
${ }^{29}$ DORNELLES, João Ricardo W. Op. Cit. p, 161.

${ }^{30}$ Leonel Brizola estava na corrida presidencial, dessa forma, o último ano do governo foi dirigido pelo advogado criminalista e vice-governador do Rio de Janeiro, Nilo Batista.
} 
muito frágil politicamente sem que pudesse rejeitar a implementação de uma política que, definitivamente, ia contra os ideais do mesmo.

Basicamente, a "Operação Rio" estipulava que um órgão dirigido pelo chefe do Comando Militar do Leste pudesse coordenar, planejar e unificar a atuação da Secretaria de Justiça, da Polícia Militar, Civil e Defesa Civil para combater a criminalidade que assolava o Estado. Durante o convênio, o governo federal também intensificava o patrulhamento assim como o controle das vias aéreas, terrestres e marítimas de acesso ao Rio de Janeiro na intenção de acabar com o tráfico de drogas e armas. Essa medida de intensificação de patrulha das vias pelas quais as armas e drogas entravam no Estado foi diversas vezes solicitada pelo então governador Nilo Batista. ${ }^{31}$

Além da patrulha e controle das fronteiras para acabar com as rotas de contrabando que as drogas e armas usavam para entrar no Estado e chegar nas mãos dos traficantes, ainda no início da Operação Rio, tropas federais e polícia ocuparam várias favelas do Rio de Janeiro e, até mesmo, negaram entrada à imprensa. No governo de Marcello Alencar, em 1995, jornalistas e fotógrafos foram agredidos por militares enquanto faziam a cobertura da ocupação em algumas das favelas do Complexo do Alemão. ${ }^{32} \mathrm{Nem}$ mesmo esse fato que lembrava os sombrios tempos da recém-encerrada ditadura militar foi suficiente para encerrar a Operação Rio. O governador Marcello Alencar e o então presidente Fernando Henrique Cardoso prorrogaram o estado de sítio até

\footnotetext{
${ }^{31}$ DORNELLES, João Ricardo W. Op. Cit., p, 167.

${ }^{32} \mathrm{O}$ complexo do Alemão é um bairro da Zona Norte do Rio de Janeiro onde há várias favelas, sendo a mais conhecida o Morro do Alemão, que durante muitos anos foi considerada uma das áreas mais violentas da cidade.
} 
março de 1995 e logo em seguida iniciou-se a "Operação Rio II". A lógica beligerante da segurança pública passou a imperar e as favelas tidas como território inimigo a ser conquistado.

É interessante notar que essa lógica belicista trás um novo elemento que reforça o caráter de inimigo. Antes, o discurso se atinha aos grupos perigosos ou às classes pobres. Com a nova lógica de forças armadas e a favela como ninho de traficantes, se intensifica o elemento geográfico tanto do discurso quanto da prática. A favela é território a ser conquistado, logo, todos aqueles dentro das favelas estão atrás das linhas inimigas, sendo, consequentemente, inimigos ou suspeitos. Não que essa lógica já não existisse. O próprio processo de favelização já leva consigo esse caráter diferenciador e excludente. A presença de forças armadas, no entanto, expressão da força nacional faz com que a ideia de que os que estão na favela estão contra os cidadãos brasileiros ganhe uma imagem objetiva.

\subsection{3 - VOLTA DA LEI E ORDEM.}

No ano de 1995 tem início no Estado do Rio de Janeiro o mandato de Marcello Alencar do PSDB. No âmbito federal, o presidente Fernando Henrique Cardoso - também do PSDB - apresentava o Plano Real como salvação dos problemas pelos quais o país passava. Foi, portanto, um momento de avanço e consolidação das ideologias e práticas neoliberais no cenário brasileiro, onde o Estado passava a se atrofiar nas questões sociais e ia se apequenando em relação às questões econômicas gerando cortes de gastos públicos, privatizações e beneficiando o capital financeiro internacional. Como 
já vimos, esse estado que se pretende um anão na economia, acaba por se tornar um gigante no âmbito penal. Esse Estado que promove conflitos ao invés de solucioná-los, no caso do governo de Marcello Alencar, chegou a implantar uma medida que ficou conhecida como "gratificação faroeste". Consistia simplesmente em uma premiação em dinheiro para os policiais, civis e militares que participavam de grandes operações e promoções por "atos de bravura". Não é necessário dizer que o número de mortes em confrontos disparou. Ao mesmo tempo, isso gerou um estímulo do governo para que os policiais cometessem execuções sumárias de delinquentes e até mesmo de suspeitos, gerando uma verdadeira política de extermínio.

A grande mídia, jornais e meios de comunicação, por sua vez, deram seu apoio ao projeto neoliberal excludente de segurança pública, manipulando as notícias de forma que o foco deixava de ser a violência e sentimento de medo da população. Dessa forma, ao parar de vender a cidade do Rio como um lugar inseguro, onde impera o medo e a criminalidade, faz-se com que se crie uma falsa ideia no imaginário social de que a violência e criminalidade estavam sob controle perfeito do Estado.

A política de segurança adotada implantou a lógica militarizada da polícia através do discurso de eficientismo penal totalmente indiferente à ideia de proteção dos Direitos Humanos e garantias constitucionais mínimas de todos os cidadãos. Dessa forma, através de uma lógica belicista, da presença das forças armadas, da relação íntima entre exército e polícia e do discurso de um eficientismo penal, a segurança pública passa a ser confundida com segurança interna, ideia herdada da ditadura militar. É aqui que o inimigo da 
sociedade passa a ser inimigo interno e que o traficante passa a ocupar o lugar do comunista.

Para a visão reacionária da direita antidemocrática, uma vez que se encontra um inimigo interno que ameaça toda a estrutura social e a ordem necessária para que a sociedade se mantenha em um estado civilizado, rompese com a possibilidade de solução de conflitos e passa a ser necessária a administração de uma sociedade em guerra. Aqui, voltamos ao conceito de "necessidade" do Direito Penal do inimigo que se utiliza dessa premissa para suspender ou até mesmo ignorar direitos fundamentais e garantias legais - base das sociedades democráticas de direito - sob o argumento de ordem pragmática de um realismo político.

Essa concepção de realismo político passa a afirmar que o conflito social não se resolve pela clássica via da cidadania, dos canais institucionais democráticos, da negociação política ou do pacto entre as forças sociais contraditórias. As contradições e os conflitos seriam resolvidos com o uso da força, com o entrechoque não regulado onde o limite é a destruição do "outro". 33

O modelo neoliberal implementado, por consequência, aplica políticas de segurança pública que enxergam a violência como um ente autônomo e isolado da sociedade. Só enxergam a violência em sua forma subjetiva como uma anomalia social, ao invés do resultado de interações sociais diversas onde a violência é apenas o resultado objetivo das contradições e estruturas da sociedade. ${ }^{34}$ Logo, essas políticas tem seu direcionamento somente para

\footnotetext{
${ }^{33}$ DORNELLES, João Ricardo W. Op. Cit. p, 180

${ }^{34}$ ZIZEK, Slavoj. Violência. São Paulo: Boitempo, 2014. É trabalhada a ideia de dois tipos de violência na sociedade: violência objetiva e a subjetiva. A primeira se relaciona à violência inerente a um sistema. São formas mais sutis de coerção que sustentam relações de exploração e
} 
controle de uma determinada população e manutenção de uma "ordem" pública, onde ordem significa os padrões comportamentais e morais impostos pela sociedade de consumo conservadora que tem no neoliberalismo sua expressão política mais atual. Sendo assim, exclui-se social e geograficamente as pessoas e as classes pobres passam a ser os "perigosos" moradores das "zonas criminógenas".

A lógica de guerra, ao entender o morador da favela como potencial delinquente e, consequentemente, um ente perigoso ao qual não se estende o status de pessoa, possibilita e legitima a humilhação dos moradores, a violência, tortura e execuções sumárias, revistas e detenções arbitrárias e ilegais, tudo isso sob um regime de sítio onde a favela passa a sofrer um cerco que impossibilita o exercício dos direitos mais básicos como o direito de ir e vir.

No plano discursivo, essas medidas são amparadas e defendidas através da propagação para a sociedade de que os princípios de direitos humanos são aqueles invocados somente para a defesa dos bandidos. Exemplo disso é a maneira como os reacionários muitas vezes se referem, informalmente, às garantias constitucionalmente asseguradas como "direito dos manos". Há, porém, uma dimensão ainda mais forte que definitivamente nega o status de pessoas aos delinquentes e suspeitos de práticas de crimes somente os oriundos das classes pobres - em que nem mesmo se aceita que esses indivíduos possam ser sujeitos aos quais esses direitos são direcionados.

dominação na sociedade. A segunda por sua vez é a violência que temos em nosso imaginário. Ou seja, a violência e agressividade entre sujeitos. 
Essa concepção fica clara na máxima do senso comum de "direitos humanos para humanos direitos".

Através desses discursos podemos dizer que foram criadas duas imagens antagônicas. De um lado, se encontram os transgressores, delinquentes e excluídos que residem ou são oriundos da periferia, das ruas ou das favelas. O morro é sinônimo de área perigosa assim como favela. Do outro lado, estão os moradores do "asfalto" que são considerados civilizados, ordeiros, contribuintes, todos reunidos sob o título - autointitulado - de "cidadãos de bem". 35

A metáfora da guerra, portanto, gera, necessariamente, uma rejeição do conceito de direitos e garantias fundamentais, pois antagoniza o conceito de cidadania e direitos humanos. O discurso eficientista opera em uma lógica que se retroalimenta, pois destrói a ideia de direitos humanos em sua dimensão de valor ético universal ao mesmo tempo em que desumaniza aqueles que entendem como perigosos, violentos e danosos à sociedade.

E são estas concepções conservadoras e reacionárias que fundamentam o processo de apartação social e exclusão. Observamos como parte da imprensa e das autoridades públicas tratam a juventude da periferia e a "invasão" das praias da Zona Sul carioca pelas "hordas de bárbaros" que, em massa, vêm dos bairros populares, das favelas, da baixada Fluminense e da Zona Oeste. [...] E esta concepção se enraíza no imaginário social, criando um ambiente de conflito entre os considerados cidadãos, "pessoas honestas", "de bem", "cumpridoras dos seus

\footnotetext{
${ }^{35}$ Interessante notar que a expressão "cidadão de bem" (Good citizen) era o nome do periódico mensal americano do início do século XX, que promovia o antissemitismo, a supremacia branca e apoiavam a Ku Klux Klan.
} 
deveres", "civilizados", por um lado, e os "bárbaros", “incivilizados", "suburbanos", "bandidos", "perigosos", por outro. ${ }^{36}$

É virtualmente impossível que o Estado, por mais militarizado e repressor que seja, esteja presente em todos os lugares. Uma consequência natural desse processo de exclusão social e desumanização dos considerados inimigos aliado à intensificação do discurso do medo e do caos gera, inevitavelmente, o vigilantismo. Constrói-se a ideia de que ao não cumprir o seu papel de oferecer segurança a todos os "cidadãos de bem", nada mais justo e legítimo que os mesmos o façam por conta própria. Sendo assim, pautas como o armamento da população encabeçadas por fabricantes de armas e a legitimação de grupos de extermínio compostos por policiais que atuam às margens da legalidade e sem o controle do judiciário passam a ganhar força dentro da sociedade. Essa prática tem gerado inúmeros acontecimentos bárbaros na cidade e contribuíram, de forma expressiva, para o surgimento das milícias que hoje controlam várias áreas da cidade extorquindo moradores e operando como uma máfia, que verdadeiramente são.

Um caso emblemático recente, consequência desse processo e que foi motivo de muita discussão na cidade, foi o caso do jovem acorrentado a um poste e espancado. ${ }^{37} \mathrm{O}$ caso causou muita discussão na mídia e na imprensa, sendo noticiado em todos os jornais. Nas redes sociais, em meio a algumas

\footnotetext{
${ }^{36}$ DORNELLES, João Ricardo W. Op. Cit. p, 187.

${ }^{37} \mathrm{Em}$ janeiro de 2014, no bairro do Flamengo, um jovem, negro, menor de idade, suspeito de praticar furtos, foi preso a um poste depois de ter as roupas arrancadas. Além de espancado o jovem ainda levou uma facada na orelha. A imagem foi comparada ao antigo pelourinho visto que o jovem foi preso ao poste por uma trava de bicicleta na altura do pescoço.
} 
manifestações racionais, não faltou quem legitimasse a ação vociferando discursos de ódio em manifestações que deixariam tímidos até mesmo os oficiais da Schutzstaffel das décadas de trinta e quarenta.

Esses discursos ganham espaço no cenário do neoliberalismo que, através do eficientismo penal que dá bases a políticas excludentes de combate à violência, acaba estabelecendo uma fronteira entre o "morro" e o "asfalto" e "cidadãos de bem" contra "criminosos". A política de confronto implementada no Estado do Rio de Janeiro somente serviu para criar mais mortes e violência contra determinada parte da população. Os delinquentes e suspeitos da prática de crimes sofrem através de execuções sumárias, torturas e supressão de direitos constitucionalmente assegurados. Os policiais são mandados para confrontos onde arriscam a vida desnecessariamente (afinal, esses policiais de baixo escalão que arriscam a vida também se encontram na camada mais pobre da população e também são alvos do processo de extermínio de negros e pobres). Por fim, o resto dessa população fica em um fogo cruzado onde a bala perdida parece sempre achar as vítimas que compartilham das mesmas características. Por todo exposto, fica claro que o modelo de eficientismo penal que orienta o modelo de segurança pública da sociedade neoliberal se mostra a expressão do Direito Penal do inimigo na sua ânsia de eliminação do ente perigoso.

\section{5 - TOLERÂNCIA ZERO.}

A política da tolerância zero, que integra o discurso de lei e ordem, nasceu nos Estados Unidos e, através de muito marketing e de um discurso 
pseudo-intelectual, acabou ganhando muita força no resto do mundo ocidental. Essa política tem origem em uma premissa positivista, racista, característica de uma nova direita americana neoliberal. Para esta última, a parte mais pobre da população não o é por falta de oportunidades e exclusão social, mas sim porque são naturalmente as pessoas com menos inteligência, mais propensas a delinquir e serem desordenadas, incapazes de alcançar resultados superiores que os tirem da pobreza ou que lhes garantam uma vida mais confortável e de acordo com os bons costumes. Em outras palavras, as pessoas seriam pobres e delinquentes, pois são, também, mentalmente e moralmente inferiores. Essa desordem na qual vivem é o terreno natural do crime. Uma vez que esse positivismo entende que os pobres têm um coeficiente de inteligência mais baixo por razões naturais, a desigualdade social deve ser encarada também como algo natural. Nesse sentido, o Estado não deve ser provedor de políticas de inclusão social ou intervir para diminuir desigualdades, já que isso só pioraria a situação. Dado que essas pessoas são pobres e vivem de forma imoral por sua própria inferioridade intelectual, alocar recursos do Estado para mudar a realidade seria um gasto irresponsável do dinheiro público, além de ineficaz, pois mesmo com os recursos providos pelas políticas sociais, essas pessoas seriam incapazes de se desenvolver. Por isso, mais eficiente seria alocar esse recursos em políticas para atividades mais lucrativas, como o setor financeiro, por exemplo, ou na segurança pública para que esses grupos perigosos sejam monitorados e controlados.

O Manhatan Institute, um instituto que financia e divulga as pesquisas acadêmicas desse novo neoliberalismo nos anos noventa e tem grande influência na formação da opinião pública, conseguiu fazer com que a teoria "broken windows", ou janelas quebradas, ficasse bastante conhecida e divulgada. Essa teoria propõe que o modo mais eficaz de se lutar contra a 
desordem e ilegalidades do dia a dia é a repressão aos pequenos delitos, defendendo que, através dessa prática, as grandes patologias criminais seriam resolvidas. A teoria nunca foi confirmada empiricamente, no entanto, serviu de base criminológica para muitos governantes.

É então que, em Nova Iorque, o prefeito Rudolph Giuliani adota a chamada doutrina da tolerância zero. Os agentes policiais passam a perseguir e repreender com firmeza e severidade a pequena delinquência e desordem de rua. A população pobre que fica nas ruas, como pichadores e prostitutas, passam a ser alvo da repressão, assim como mendigos passam a ser presos cotidianamente. Essa política tem como alvo, na realidade, o sentimento de segurança da classe média e dos ricos. Isso é feito com o aumento do efetivo policial, além de alocação de recursos para as polícias. Em suma, o que a política de tolerância zero faz, em última análise, é criminalizar a pobreza e higienizar as ruas para que as classes pobres não sejam mais vistas pelo resto da sociedade e assim os "cidadãos de bem" possam se sentir mais seguros longe dos perigosos e imorais. Ademais, reforça e auxilia a política do encarceramento em massa, já que aumenta a repressão penal de delitos em que os autores são vulneráveis e sem condição de pagar por uma defesa efetiva.

No caso do Rio de Janeiro a importação da tolerância zero recebeu o nome de "choque de ordem" durante os mandatos do prefeito Eduardo Paes. Assim como na versão americana, o que se pretendeu no Rio de Janeiro foi exatamente combater a "desordem urbana" como forma de amenizar a sensação de insegurança da população. Essa foi, e ainda é, a justificativa oficial dessa política. Ela esconde outros interesses, no entanto, principalmente do capital imobiliário. Na zona sul da cidade - área onde, tradicionalmente, 
moram as pessoas com mais dinheiro, além de ser cartão postal como área turística - o foco da política foi no recolhimento (e não acolhimento) de mendigos, reboque de carros parados em lugares irregulares com aplicação de multas, demolição de casas (pobres) em áreas ambientais e na repressão do trabalho informal. Os chamados "camelôs", trabalhadores da economia informal que não conseguem ser absorvidos pelo mercado, são pequenos vendedores dos mais diversos produtos imagináveis, que se espalham por vários pontos da cidade vendendo seus produtos a preços muito mais acessíveis do que nas grandes lojas. Não raramente vemos a polícia prendendo esses camelôs na rua, destruindo seus produtos ou até mesmo tomando-os para si. Isso depois de uma sessão de humilhação e violência em público.

A ordem também chegou às praias da cidade. Somente os ambulantes cadastrados passaram a ter permissão de vender produtos nas praias para os banhistas. Ao mesmo tempo, atividades de lazer como a "altinha" - brincadeira onde as pessoas passam a bola com os pés sem que a mesma caia no chão - e o "frescobol" - esporte criado no Rio de Janeiro - foram proibidos e apenas permitidos em horários em que ninguém mais se encontra na praia. Essas proibições muitas vezes geraram confrontos entre banhistas e policiais da guarda municipal que foram parar nos noticiários e nas primeiras páginas dos jornais de maior circulação do país.

Em 2011, o governo municipal lança um novo projeto chamado de Unidades de Ordem Pública (UOPs). É lançado como uma nova forma para atuação no combate à desordem urbana para garantir o choque de ordem permanente nos bairros. O policiamento e fiscalização ocorrem 24 horas por dia, todos os dias. E como não seria surpresa nenhuma, dentre os cento e 
sessenta bairros que constituem o município do Rio de Janeiro, as primeiras sete UOPs foram instaladas para atender os bairros Leblon, Ipanema, Copacabana, Tijuca, Centro, Méier, a região do Porto Maravilha, Catete, Flamengo e Glória. Uma breve olhadela no mapa da cidade já mostra como que, geograficamente, essa medida contempla os bairros nobres e a região turística da cidade. Ou seja, literalmente, o Choque de Ordem foi desenhado para que os ricos deixem de conviver diariamente com os pobres e se sintam mais seguros, além de promover incentivo ao capital imobiliário e turístico.

Vemos então que, enquanto consagra um Estado mínimo de intervenção econômica, deixando que o mercado se auto regule pelas leis de oferta e demanda comandados pelos interesses de quem detêm o capital, principalmente o financeiro, o Estado neoliberal conclama um Estado máximo no que tange à intervenção penal. Enquanto conclama menos regulação e intervenção econômica, o Estado neoliberal também oferece maior contingente e recursos destinados às polícias e agências do sistema penal com o fim de reprimir as classes vulneráveis, constrói mais cadeias e aumenta o número de tipos penais - assim como as penas, principalmente, para os delitos de rua. Nesse sentido, com uma das mãos aumenta o poder daqueles que tem mais influência política e econômica e, com a outra, sufoca os pobres.

\section{6 - UNIDADES DE POLÍCIA PACIFICADORA (UPPs).}

\subsection{1 - se vis pacem, para bellum}


Antes de tudo, apesar de podermos separar as políticas de tolerância zero e política das UPPs, é preciso entender que ambas fazem parte de um quadro mais amplo e interligado, sendo apenas dimensões diferentes do processo de criminalização da pobreza e da atuação do Direito Penal do inimigo.

A estratégia do poder público para lidar com o fenômeno criminal sempre foi o confronto direto em um embate de forças que colidem diretamente. A partir dessa visão parcial e limitada, a única solução para que se sobreponha aos marginais é, obviamente, o aumento da força. Essa lógica simplista e oligofrênica acabou gerando uma verdadeira corrida armamentista que proporcionou a escalada do poder de fogo de ambos os lados.

A lógica é mais armas, mais munições, mais blindados, mais efetivos policiais, ou seja, mais do mesmo. A escalada toma proporções tão grandes que se deparar com uma viatura policial com fuzis apontados para fora nas ruas e avenidas da cidade já é algo rotineiro e banal. O equipamento usado pela polícia deveria ser restrito ao uso das forças armadas e é bem comum encontrar os mesmo tipos de armas em lugares ao redor do globo que se encontram efetivamente em guerra.

A preocupação do poder público, que devia estar voltada para atenuar o tráfico de armas e diminuir sua circulação, acaba por ter o efeito inverso, 
colocando mais armas em circulação e aumentando seu potencial bélico e o número de mortos e feridos em confrontos. ${ }^{38}$

Com isso, podemos concluir que quanto mais se investir em confronto direto na utilização de maior poder de fogo, maior será a letalidade do conflito em ambos os lados. A escolha por um modelo de enfrentamento direto ao problema da criminalidade, principalmente no que diz respeito às áreas de favelas onde as facções que comandam o tráfico de drogas ilícitas se fazem presentes, é um modelo equivocado que só agrava os problemas que pretende solucionar. O melhor caminho para lidar com a criminalidade, ao contrário do que propõe aqueles de visão limitada e reducionista, passa exatamente pela retirada do armamento de circulação.

Não obstante o que foi dito, não foi esse o caminho seguido pelo Estado. Pelo contrário, a fé na proposta belicista para solução dos conflitos violentos na cidade do Rio de Janeiro dá um passo à frente em sua campanha marcial e surge com o projeto de "pacificação" das áreas dominadas pelo tráfico de drogas, seguindo a linha do provérbio latino "se vis pacem, para bellum. ",39

\footnotetext{
${ }^{38}$ Resolução 19/2011 da Assembleia Legislativa do Rio de Janeiro. A comissão parlamentar de inquérito verificou que grande parte das armas usadas para cometer crimes na mão de traficantes de drogas pertence ou pertenceu a policiais. Também aponta que $82 \%$ das armas no país são de produção nacional, o que acaba com o mito de que o problema seriam as fronteiras com países vizinhos, mas aponta que na verdade o problema é a fiscalização das armas produzidas no próprio país.

${ }^{39}$ Provérbio latino que pode ser traduzido como: "se quer paz, prepare-se para a guerra".
} 
No início de sua implementação, as Unidades de Polícia Pacificadora (UPPs) traziam no discurso que reconheciam e entendiam as desigualdades geradas por um sistema de exclusão geográfica e social da cidade do Rio de Janeiro. Dessa forma, junto as UPPs havia o projeto das UPPs sociais, no qual haveria a inclusão dos moradores no processo de expansão dos serviços públicos básicos para as comunidades carentes junto com a chegada da polícia. Ou seja, o discurso oficial era de que o Estado não só levaria a polícia, mas também serviços de educação, saúde, saneamento, coleta de lixo, iluminação, urbanização e infraestrutura para as áreas historicamente abandonadas pelo poder público. Isso tudo contando com a participação direta dos moradores, com o fim de tornar o processo mais democrático, além de atender às necessidades específicas de cada área.

Com a criação das UPPs, as áreas chamadas de pacificadas realmente começam a perceber a presença do Estado. Os furtos de luz, de TV a cabo e outros serviços que eram realizados de maneira informal passam a ser fiscalizados e reprimidos. Ao mesmo tempo, os moradores que antes se utilizavam desses recursos para obter os serviços informalmente, agora necessitam pagar as taxas e tributos decorrentes dessa prestação que passam a ser cobradas com valores muito mais altos, similares aos praticados em outras áreas "nobres" da cidade. Com a "paz" que chega às áreas pacificadas, os serviços privados também passam a entrar nas comunidades e aumentar o custo do espaço urbano favelizado. Isso quer dizer que o custo de vida dessas áreas aumenta, já que agora o Estado leva a cobrança e o setor privado passa a operar. Em compensação, a renda dessa população não segue esse acréscimo, pois não são oferecidas maiores oportunidades de trabalho, de inclusão no mercado ou de melhoria substantiva na qualidade de vida das mesmas. Isso 
leva muitos moradores a terem de sair do local que habitavam em busca de lugares mais baratos e acessíveis à sua realidade financeira.

Mais do que isso, um olhar mais atento à estratégia de implementação das UPPs, no que diz respeito à geografia de sua implementação, faz saltar aos olhos os interesses subjacentes dessa política. $\mathrm{O}$ fato de ela estar restrita a algumas favelas específicas da Zona Sul, Norte e Centro da cidade, mostra o interesse escondido da "ocupação militar e verticalizada das áreas de pobreza que se localizam em regiões estratégicas aos eventos desportivos do capitalismo videofinanceiro." ${ }^{40}$

A título de exemplo, em novembro do ano de 2010 acontece a "retomada" do Complexo do Alemão, uma operação monstruosa que contava com largo efetivo - soldados e agentes das polícias civil e militar, além do apoio de pessoal e veículos cedidos pelo exército e marinha. Essa operação se inicia com o cerco ao Complexo do Alemão. A lógica era a de se sobrepor ao poder dos traficantes que dominavam a favela e que pertenciam à organização criminosa mais antiga e violenta do Rio de Janeiro. ${ }^{41}$ Após um ultimato para que os delinquentes que se encontravam no morro baixassem as armas e se entregassem, a polícia inicia a operação de "retomada" do Complexo do Alemão.

\footnotetext{
${ }^{40}$ BATISTA, Vera Malaguti, O alemão é muito mais complexo. In: BATISTA, Vera Malaguti (org). Paz armada. Rio de Janeiro: Revan. 2012. p, 58.

${ }^{41} \mathrm{O}$ chamado Comando Vermelho (CV) foi formado no fim dos anos setenta. Alguns de seus líderes ficaram muito conhecidos e temidos na cidade como Fernandinho Beira-Mar, Marcinho VP e Elias Maluco.
} 
A operação foi televisionada em tempo real pelas maiores emissoras de televisão do país, que cobriam a operação de forma ininterrupta. Algumas emissoras chegaram até mesmo a reorganizar a sua grade de programação para transmitir a operação sem interrupções, já prevendo o sucesso de audiência que seria. Grande parte da população, por sua vez, assistiu à transmissão como um megaevento de entretenimento e, como em uma produção hollywoodiana, torciam para que os "mocinhos" acabassem com os "bandidos" ao final do filme.

O ápice da operação foi um momento registrado pelas câmeras de um helicóptero que sobrevoava o morro para cobertura jornalística e que seria reproduzido durante dias em todos os noticiários, redes sociais, sites de notícias e qualquer plataforma de mídia de vídeo: nesse momento, vendo o avanço dos policiais, vários homens armados saem em disparada, fugindo desesperadamente para outra favela, se amontoando em carros ou na garupa de motos e até mesmo a pé. As câmeras conseguem registrar, ao vivo, um desses homens sendo atingido, caindo no chão e recebendo ajuda de outro companheiro que também fugia. A cena, que poderia ser facilmente confundida com um filme de guerra para quem não soubesse do que se tratava, foi comemorada por grande parte dos telespectadores que ansiavam pela execução sumária dos traficantes que corriam para salvar suas vidas e, assim, acabar com o inimigo.

Após o recuo dos traficantes e a chegada das forças policiais ao topo do morro, foram hasteadas as bandeiras do Brasil e do Estado do Rio de Janeiro pelos policiais que, por causa de seus equipamentos e uniformes, mais pareciam soldados em um front. Essa imagem, que também foi amplamente 
repetida nos noticiários, só mostra como a lógica e o ambiente configuram uma verdadeira guerra, agora em sentido literal. É interessante notar que o próprio secretário de segurança pública, José Mariano Beltrame, reproduz essa lógica dizendo que:

O Alemão provou a viabilidade de as polícias estaduais e federais atuarem em conjunto com as Forças Armadas, sob uma coordenação centralizada. Em quatro dias, foi recuperado um território que - assim se imaginava - levaria um mês para ser dominado. ${ }^{42}$

O simbolismo de hastear a bandeira nacional em um território conquistado mostra como aquela área não era nem mesmo considerada parte do Estado brasileiro e a população, por conseguinte, não poderia ser considerada cidadã desse Estado. Foi território conquistado e seus governantes (traficantes) expulsos ou mortos.

\subsection{2 - OCUPAÇÃO.}

Comunidade que vive à vontade

Com mais liberdade tem mais pra colher

Pois alguns caminhos pra felicidade

São paz, cultura e lazer

Comunidade que vive acuada

Tomando porrada de todos os lados

Fica mais longe da tal esperança

Os menor vão crescendo tudo revoltado

E não se combate crime organizado

Mandando blindado pra beco e viela

Pois só vai gerar mais ira

$\mathrm{Na}$ gente que mora dentro da favela

\footnotetext{
${ }^{42}$ BELTRAME, José Mariano. Todo dia é segunda-feira. Rio de Janeiro: Editora Sextante. 2014. p, 145.
} 
Sou favelado e exijo respeito

Só são meus direitos que eu peço aqui

Pé na porta sem mandato

Tem que ser condenado

Não pode existir

Tá tudo errado

É até difícil explicar

Mas do jeito que a coisa tá indo

Já passou da hora do bicho pegar

Tá tudo errado

Difícil entender também

Tem gente plantando o mal

Querendo colher o bem

Mãe sem emprego

Filho sem escola

É o ciclo que rola aqui nesse lugar

São milhares de histórias

Que no fim são as mesmas

Podem reparar

Sinceramente eu não tenho a saída

De como devia o tal ciclo parar

Mas do jeito que tão nos tratando

Só estão ajudando esse mal se alastrar

E morre polícia, morre vagabundo

E no mesmo segundo

Outro vem ocupar

O lugar daquele que um dia se foi

Pior que depois geral deixa pra lá

Agora amigo, o papo é contigo

Só um aviso pra finalizar

O futuro da favela depende do fruto que tu for plantar

(Tá Tudo Errado - Mc Leonardo e Mc Júnior)

Depois de "dominar" as favelas - para usar um termo do próprio secretário de segurança - e instalar as UPPs garantindo a presença das forças policiais nos territórios recuperados, a manutenção da lei e da ordem precisa ser respeitada e assegurada, afinal, antes eram praticadas as leis do tráfico nas áreas que foram pacificadas. Sendo assim, uma série de medidas precisa ser tomada para que as favelas passem a se comportar de acordo com as normas do resto da cidade que se encontra na legalidade. 
O que se observa é que após chegada das Unidades de Policia Pacificadora nas favelas, instala-se um verdadeiro Estado de Polícia nas áreas ocupadas. São regras e ordens absolutamente inconstitucionais que ferem os direitos e garantias fundamentais previstos no artigo $5^{\circ}$ da própria constituição. Toques de recolher, revistas arbitrárias, proibição de eventos culturais e até censura da manifestação de pensamento. A verdade é que, com a ocupação das favelas, se instala um verdadeiro regime que só poderia ser concebido ou imaginado perante a decretação do Estado de Defesa ou Estado de sítio.

A Constituição brasileira prevê, do seu artigo 136 ao artigo 139, a possibilidade da implementação do Estado de Defesa ou Estado de sítio como instrumentos para defender as instituições democráticas. Esses dois instrumentos são de tal gravidade que podem suspender e limitar, de forma rigorosa, vários direitos garantidos pela própria Constituição. Até mesmo esses instrumentos, porém, preveem limites tanto em relação às medidas que podem implementar quanto ao tempo de sua duração. A ocupação das favelas no Rio de Janeiro pelas UPPs já ultrapassa os dois e vige sem maior espanto seja da população, seja das instituições que deveriam zelar pela ordem constitucional de garantias dos direitos e liberdades. Nesse sentido, Vera Malaguti Batista é precisa ao afirmar que:

A segurança pública só existe quando ela decorre de um conjunto de projetos públicos e coletivos que foram capazes de gerar serviços, ações e atividades no 
sentido de romper com a geografia das desigualdades no território usado. Sem isso não há segurança, mas controle truculento dos pobres e resistentes na cidade. ${ }^{43}$

No mesmo sentido, a definição dos juristas Raúl Zaffaroni e Nilo Batista sobre o Estado de Polícia cai como uma luva para na situação que se passa nas áreas "pacificadas" quando dizem: "o Estado de Direito é concebido como o que submete todos os habitantes à lei e opõe-se ao Estado de Polícia, onde todos os habitantes estão subordinados ao poder daqueles que mandam." ${ }^{44}$

As ocupações da UPP, no entanto, não foram capazes de reduzir o consumo de drogas na cidade do Rio de Janeiro. À primeira vista, pode parecer que uma coisa não tem relação com a outra, mas, se as áreas onde imperava o tráfico comandado pelas facções que detinham o monopólio das drogas ilícitas agora estão sob o comando das UPPs, então onde e com quem os usuários conseguem acesso às mesmas? Essa é uma pergunta que ainda não foi de todo esclarecida, porém hipóteses plausíveis levam a crer que o tráfico de drogas está, agora, em grande parte nas mãos dos próprios policiais da UPP, seja diretamente fazendo o papel de varejista, que antes cabia aos traficantes, seja sendo complacentes com a venda nas áreas pacificadas, não reprimindo os varejistas em troca de propinas.

Não obstante a troca de pobres de fuzis por fardados de fuzis nas favelas, os problemas das comunidades que estão sob o domínio das UPPs são resolvidos pelos encarregados das unidades em questão. E, aqui, não falamos

\footnotetext{
${ }^{43}$ BATISTA, Vera Malaguti (org). Op, Cit. p, 60.

${ }^{44}$ ZAFFARONI, Eugenio Raúl et al. Direito Penal Brasileiro I. Rio de Janeiro: Revan, 2003. p.41
} 
dos delitos que acontecem nas áreas pacificadas. Esses, por óbvio, seriam de atribuição da polícia em qualquer lugar do mundo. Estamos falando da organização e dia a dia da própria comunidade. Para que aconteçam eventos, festas e demais manifestações artísticas e de entretenimento é necessário aval do comandante da UPP, que é a autoridade com poderes para permitir ou proibir a realização desses eventos.

Esse movimento não pode ser percebido sem a compreensão histórica de repressão e perseguição de toda produção artística cultural e, por conseguinte, política dos negros. A primeira proibição foi quando os escravos eram proibidos de praticar suas religiões de matrizes africanas, o que veio a gerar, além de outras coisas, um processo de sincretismo religioso que, no Rio de Janeiro, culminou com a criação da religião Umbanda. Além da religião, a próxima manifestação negra a ser não só proibida como criminalizada, foi a capoeira, seguida do samba e chegando, hoje, ao funk, "pois no Rio de Janeiro do início do século XXI, as velhas perseguições aos batuques e ao samba encontraram no funk um novo alvo à altura da tradição. ${ }^{\text {45 }}$

A proibição do baile funk acaba passando por dois argumentos que escondem seus reais fundamentos racistas e opressores. O primeiro deles diz respeito à apologia dos chamados "proibidões" ao crime e o segundo passa por um argumento que trás mais uma vez o discurso de lei e ordem que regulamenta o acontecimento dos eventos. Para Nilo Batista, esse é um processo de asfixia da cultura do funk que opera de duas formas: astúcia e força.

\footnotetext{
${ }^{45}$ BATISTA, Nilo, sobre a criminalização do funk carioca. In: BATISTA, Vera Malaguti (org). Tamborzão: olhares sob a criminalização do funk. Rio de Janeiro: Revan. 2013. p, 191.
} 
A astúcia consistiu em editar uma Resolução conjunta, de várias secretarias de Estado, que formula tantas e tão dificultosas exigências para a realização de bailes funk que praticamente os inviabiliza. É inacreditável que essa Resolução ainda não tenha sido declarada inconstitucional por um Tribunal. A força manifestou-se nos diversos procedimentos policiais e judiciários que tentaram criminalizar alguns artistas, especialmente Mcs, do funk carioca. ${ }^{46}$

Esse processo mostra como a ocupação das favelas pelas UPPs, ao contrário do que se veicula nos discursos das emissoras, jornais, mídias em geral e do senso comum, na verdade agrava a situação dessas comunidades e "aprofundam desigualdades e as segregações socioespaciais no Rio de Janeiro" ${ }^{47}$. É a clara implementação, não mais da metáfora da guerra, mas sim da guerra propriamente dita dentro do Estado. É a consolidação da negação de status de pessoas aos que habitam nesses territórios e seu reconhecimento como ente perigoso, suspeito. Nesse sentido, é a prova da conclusão de Schmitt de que a noção do inimigo leva, necessariamente, ao Estado absoluto e à guerra permanente.

É preciso consciência, além de muita coragem para enfrentar a criminalização da pobreza, modalidade do Direito Penal do inimigo e semente do Estado totalitário do neoliberalismo. A cidade do Rio de Janeiro é historicamente palco de muitos dos embates políticos e sociais que fizeram e fazem parte dos rumos políticos do país. Nossa cidade tem a peculiaridade geográfica que, por um lado, acirra os conflitos, mas que, por outro, os põe em evidência diariamente. É, portanto, lugar mais do que propício para implementação de modelos de sociedade realmente democráticos e inclusivos. É um lugar onde pode nascer a semente de uma nova maneira de se pensar a

\footnotetext{
${ }^{46}$ Ibid. p ,191.

${ }^{47}$ BATISTA, Nilo. Op, Cit. p, 58.
} 
sociedade fora da lógica simplista que vem sendo posta em prática desde sempre, com alguns sopros de racionalidade unidos à empatia. Podemos retomar os rumos que, até pouco tempo, foram apresentados pelo governo Brizola - Nilo Batista em direção a uma mudança real que efetive os preceitos constitucionais e democráticos previstos pela Constituição de 1988, visando o respeito às garantias e a promoção dos direitos humanos e da cidadania para todos. 


\section{CAPÍTULO 4 - PROPOSTAS DE CONTEÇÃO DO PODER PUNITIVO.}

Até aqui, vimos como o inimigo é criado a partir da noção de periculosidade que vai legitimar o seu não reconhecimento como pessoa permitindo, assim, a supressão ou negação das garantias fundamentais e dos diretos humanos. Também vimos como o Direito Penal do inimigo se apresenta, não só nos discursos penais, como também nas práticas e políticas promovidas pelo Estado. E, por último, vimos como a construção da imagem do inimigo coincide com as características da população mais vulnerável e das classes pobres servindo, assim, para o controle das classes entendidas como perigosas que, na verdade, é aquela parcela da população excluída de uma sociedade de consumo e sem utilidade, portanto descartáveis, para o modelo neoliberal.

Devemos rechaçar de plano uma proposta de contenção do poder punitivo como defendida por Jakobs. É verdade que se pode concordar com praticamente tudo o que o professor alemão argumenta a título de descrição da realidade e do ordenamento jurídico como já imbuídos da figura do inimigo. Também podemos concordar que, ao tentar tratar do inimigo dentro do Direito Penal do cidadão, o que ocorre é que direito material e processual acabam por misturar a figura do cidadão com a figura da "não-pessoa", fazendo com que se cometam injustiças colossais. É preciso discordar, no entanto, de Jakobs quanto à criação de um compartimento autônomo que se proponha a conter em prescrições próprias o inimigo. Isso porque, como bem aponta Zaffaroni, essa

proposta parte de uma visão estática da realidade que não percebe que a sociedade é histórica, que se reconstrói e molda constantemente e esse 
movimento também influi na dinâmica do poder. ${ }^{48}$ Sendo assim, o compartimento que se pretende construir será sempre insuficiente para conter o movimento do poder punitivo e, inexoravelmente, acabará por deixá-lo livre.

Frente à percepção de que o poder punitivo do Estado só tende a aumentar a partir da ideia do inimigo, é preciso então que se contenha essa expansão para que não cheguemos ao fim último e inevitável da aceitação da figura do inimigo, que é o Estado absoluto policialesco e totalitário. De fato, não são as ações daqueles entendidos como inimigo que são capazes de destruir o Estado e a sociedade, como propõe aqueles que legitimam esse tratamento diferencial. É a própria aceitação da ideia que efetivamente tem a capacidade de fazer o Estado democrático ruir, pois, ao introduzir o conceito do inimigo, necessariamente os limites do Direito Penal e da guerra passam a se confundir, até que se fundem, passando a ser guerra sinônimo de Direito Penal. A noção de inimigo gera, portanto, a própria renúncia do Estado de Direito. Dessa forma, é imprescindível compreender que "o Direito Penal é um apêndice indispensável do Direito Constitucional do Estado de Direito, o qual se encontra sempre em tensão dialética com o Estado de Polícia., ${ }^{99}$

Como a Constituição traz em seu texto a positivação das garantias e direitos fundamentais como imperativos a serem respeitados por todos os ramos do Direito e que transbordam em um efeito cascata até a base do ordenamento, o Direito Penal não pode ser outro que não o que preze, antes de tudo, por essas garantias. Por isso, falar de um Direito Penal garantista não

\footnotetext{
${ }^{48}$ ZAFFARONI, Eugenio Raúl. O inimigo no direito penal. Rio de Janeiro: Revan, 2007. p, 166

${ }^{49}$ Ibid. p, 172
} 
pode ser considerado como nada além de redundância. Esse direito, na realidade, é intrínseco ao próprio Estado de Direito, uma vez que, nada mais é do que o próprio elemento que fez cambiar o paradigma do Estado absoluto para o Estado de Direito na história das sociedades ocidentais. Em outras palavras, as garantias penais e processuais nada mais são do que o próprio Estado de Direito. ${ }^{50}$

Se o Estado de polícia consegue derrubar uma barreira, deve-se construir outra, mais forte, e se derrubar muitas outras ou inclusive todas e, com isso, provocar a derrubada do Estado de direito, nem sequer em circunstâncias tão dramáticas seria lícito ao direito penal abandonar a essência do seu discurso de resistência, pois cedo ou tarde o Estado de direito renascerá. ${ }^{51}$

No plano concreto, é preciso efetivar esse discurso de garantias e previsto constitucionalmente na praxis das instituições socais. No caso da política criminal, é preciso que o conteúdo das garantias seja absorvido pelas agências que vão tratar da segurança pública, em especial da polícia. Isso significa dizer que, antes de qualquer coisa, é preciso rechaçar a ideia de que haja um inimigo na sociedade a ser combatido.

Sabemos que o modelo que nos apresenta o neoliberalismo é, nada mais nada menos, um controle social exercido pelo poder punitivo do Estado unicamente através da força e repressão. Sabemos, também, que esse exercício truculento do monopólio da força acaba sempre recaindo sobre o as classes mais vulneráveis através da repressão ao varejista do tráfico ilícito de

\footnotetext{
${ }^{50}$ Ibid. p, 173.

${ }^{51}$ Ibid. p, 177.
} 
entorpecentes alçado à figura demoníaca de traficante de drogas.

Dessa forma, a primeira conclusão lógica é de que, ao rechaçar a ideia de inimigo, a polícia deve se desmilitarizar, uma vez que não há quem combater na lógica da guerra. No momento que a polícia não mais combate um inimigo em um estado de guerra, a mesma deve passar a ser entendida como uma prestadora de serviços à sociedade, que é efetivamente o seu papel em um Estado de Direito. Ao invés de combater em uma guerra e servir para repressão de combate ao inimigo, a polícia passa a ser prestadora dos serviços de assistência e segurança da sociedade; ao invés de uma força pública com alto poder de coação, passa a ser vista como um serviço público. Nesse sentido, o professor João Ricardo W. Dornelles aponta muito bem a essência dessa instituição em um Estado de Direito como

uma polícia marcada por uma concepção democrática de sociedade significa, entre outras coisas, subverter a própria lógica da existência desta instituição. Por isso, uma polícia não como força pública, mas sim como órgão de serviço que pode, em situações especiais, e de acordo com determinações constitucionais, usar limitadamente a força. ${ }^{52}$

Através dessa concepção das instituições policiais é possível a superação de um modelo belicista de confronto - que vê nos cidadãos sempre um potencial delinquente, viola direitos humanos e ignora garantias constitucionais - possibilitando a implementação de um modelo democrático. Se na concepção belicista nós falamos de uma polícia de combate ao inimigo, no marco do Estado de Direito nós falamos não do combate ao crime, mas de sua prevenção como ideia norteadora da política criminal.

\footnotetext{
${ }^{52}$ DORNELLES, João Ricardo W. Op. Cit. p, 88.
} 
Esse modelo de controle social se mostra mais eficaz na solução de conflitos, uma vez que passa a aproximar vários segmentos sociais e setores da sociedade para que discutam e elaborem as práticas de contenção da violência, construindo, de forma conjunta e democrática, as práticas de contenção da violência atendendo às necessidades de cada parte da população assim como suas características peculiares.

A polícia passa a atuar pelo policiamento comunitário ao invés do confronto direto ou combate ao criminoso. Isso faz com que se desloque a questão criminal do autor e delinquente para que se foque na vítima. Pensa-se, antes de tudo, em prevenir o crime ao invés de reprimi-lo depois de já cometido. Essa é a consequência de se entender uma outra realidade, qual seja, a de que, antes de ser um fenômeno jurídico, o crime precisa ser entendido como um fenômeno social. O crime é a expressão de um conflito que se dá na sociedade e, sendo assim, deve ser trabalhado e resolvido também por esta junto do Estado, mas não confiscado pelo mesmo.

Quando o Estado se apropria do conflito como único legitimado a solucioná-lo, tira da vítima qualquer oportunidade de se manifestar ou de atuar para que se resolva o problema. Nosso sistema jurídico transforma a vítima em mero informante do fato ocorrido ou, quando muito, em uma catalisadora do discurso punitivo através da empatia que gera na sociedade por sua dor e sofrimento, exacerbando o sentimento de ira e vingança social. Assim, o Estado ignora todas as possibilidades de resolução do conflito sem a intervenção penal em um grave desrespeito ao princípio da fragmentariedade e da intervenção mínima. 
Quando partimos para o modelo prevencionista, a reinserção da vítima na equação possibilita que sejam encontradas soluções para os conflitos e maneiras de se atuar na sociedade de forma preventiva, possibilitando que os problemas, que muitas vezes culminam em delitos, possam ser solucionados antes mesmo de chegar ao ponto de tensão onde é praticado o crime. Essa nova concepção integra as agências de controle social de maneira que, tanto a sociedade civil quanto o Estado, trabalham juntos e se articulam para lidar com a criminalidade sob uma perspectiva que não seja simplesmente o combate ao crime.

Isso significa que a função dessa polícia comunitária é, prioritariamente, prevenir o crime, resolvendo, efetivamente, os conflitos e problemas da comunidade, atuando em conjunto com a mesma. Dessa forma, as demandas prioritárias de cada parcela da população acabam por ser definidas conjuntamente, numa relação de aproximação da sociedade civil e do Estado, representado pela instituição policial. As políticas públicas devem ser construídas conjuntamente, sendo um processo que se inicia da base para o topo e não como uma imposição vertical hierarquizada que impossibilita o diálogo. Quando essa hierarquização acontece, a população perde a confiança nas instituições do Estado e se sentem fora do processo democrático de construção da sociedade, em especial daquela comunidade onde vivem.

Quando prevalece a exclusão política e social e a maioria da população não se sente participante das esferas coletivas de decisão, a sociedade deixa de ser o espaço político da cidadania para se tornar objeto de apropriação privada e de realização de interesses pessoais, deslegitimando o monopólio do uso da violência pelo Estado e 
ampliando as condições de conflito. ${ }^{53}$

O resultado da implementação do modelo preventista através da polícia comunitária é uma melhora na qualidade de vida e na satisfação da sociedade para com o Estado, além de aumentar a sua confiança no mesmo. ${ }^{54}$ Esse modelo da polícia preventiva decorre da interpretação constitucional de respeito às garantias que, por sua vez, só pode ser realmente implementado quando se muda a lógica da guerra para a lógica de prestação de serviços à sociedade. É a lógica de que as polícias lidam com cidadãos dentro de uma sociedade democrática onde imperam os valores decorrentes do Estado de Direito. Esse, por sua vez, só pode ser perseguido quando se rechaça a figura do inimigo e se entende que todos, até mesmo os delinquentes que cometem as ações tipificadas mais graves, são cidadãos e gozam da proteção constitucional no que tange ao seu reconhecimento como pessoa digna.

\section{CONCLUSÃO.}

Inicialmente, procuramos identificar o momento histórico de aparição do inimigo dentro das sociedades ocidentais. Vimos que foi em Roma que a ideia do estrangeiro, do outro, bárbaro, alienígena e, portanto, perigoso aparece pela primeira vez dentro de um ordenamento jurídico e com uma fundamentação doutrinária que lhe legitimasse. Vimos, ao mesmo tempo, que foi em Roma, a partir da figura do hostis judicatos, que se constrói a figura jurídica de um cidadão que passa a ser entendido como perigoso ou como

\footnotetext{
${ }^{53}$ Ibid. p, 129.

${ }^{54}$ Ibid. p, 105.
} 
inimigo e, dessa forma, lhe é negado o direito e status que de alguma maneira lhe garantiriam a integridade dentro daquela sociedade.

Após apontar o surgimento do inimigo, fizemos um breve caminhar histórico passando pelas fases que mais alteraram a formação da sociedade e percebemos que a ideia de um indivíduo entendido como ente perigoso sempre foi uma constante ao longo das transformações históricas. Apesar de as sociedades se redesenharem de forma intensa, o inimigo continuou presente na teoria política, fazendo parte das discussões dos mais importantes e competentes pensadores das épocas. Cada grande transformação trouxe consigo uma nova roupagem de quem seria o ente perigoso, porém, sua essência sempre esteve presente, sendo alterado apenas superficialmente por fatores contingentes.

Debruçamo-nos, brevemente, sobre o pensamento de Günther Jakobs a respeito do inimigo. Pensamento este que gerou bastante rebuliço dentro das discussões de Direito Penal e teoria política. Primeiramente, deve-se reconhecer o mérito do professor da Universidade de Bonn de ter "dado nomes aos bois" ao chamar o tratamento diferencial de certas pessoas como Direito Penal do inimigo. Também é preciso reconhecer como, acertadamente, Jakobs descreve esse tratamento diferencial como confuso e emaranhado dentro dos ordenamentos jurídicos atuais, o que gera uma série de violações aos Direitos Humanos. É preciso, no entanto, discordar de sua proposta de contenção da expansão do poder punitivo do Estado por aceitar, além de legitimar, a ideia de um ente perigoso que, por ser nocivo à sociedade, deve ser tratado de forma diferenciada em razão da necessidade de sua contenção e, assim, lhe ser negado o status de pessoa. Essa proposta de um compartimento jurídico 
estanque para que se lide com o inimigo ignora o movimento e dinâmica do poder em uma sociedade real histórica. Inevitavelmente, a legitimação e aceitação do inimigo marcham para o Estado absoluto.

Falando mais especificamente do Rio de Janeiro das últimas duas décadas, demonstramos como se forma a figura do inimigo. Demonstramos que dentro da sociedade capitalista, onde prevalece o modelo neoliberal, o sistema cria e acirra as diferenças sociais e acaba excluindo grande parte da população de qualquer possibilidade de acesso à educação, aos bens de consumo, ao mercado de trabalho, ou seja, a possibilidade de seu pleno desenvolvimento e exercício da cidadania.

A isso somamos os preconceitos históricos do Brasil que contribuem para reforçar a exclusão social. Esse processo atinge as classes vulneráveis criminalizando a pobreza para que a parcela da população que não é útil ao modelo neoliberal seja controlada ou exterminada. Isso se dá pois o neoliberalismo, ao propor um Estado interventor mínimo na economia, ao mesmo tempo clama o Estado máximo na seara penal, já que vê no poder punitivo o controle das classes perigosas e solução das desigualdades que ele mesmo cria.

É dessa forma que a figura do inimigo vai se moldando em um jovem, negro, morador da favela ou periferia, não absorvido pelo mercado e que encontra no varejo do tráfico de entorpecentes as condições e oportunidades de uma vida mais confortável. O senso comum, a opinião pública e publicada, a grande mídia e os setores mais conservadores da sociedade contribuem para a 
criação de um personagem diabólico na figura do grande traficante de drogas e chefe do morro. A partir dessa imagem, a cultura do medo é amplamente difundida e gera uma atmosfera que convence as pessoas de que somente medidas urgentes e necessárias darão cabo de solucionar os problemas de violência e criminalidade. É esse discurso e esse imaginário social que legitima as políticas de combate à criminalidade, de guerra às drogas e de tolerância zero na modalidade do choque de ordem no caso do Rio de Janeiro. Esse medo generalizado legitima ações que suspendem ou negam garantias constitucionalmente asseguradas e reforçam os próprios estigmas das classes pobres em um ciclo vicioso de violência que é útil ao sistema capitalista neoliberal.

A política criminal que se adota é a política criminal do inimigo, que se norteia a partir da lógica da guerra fazendo com que a polícia tenha de lidar com o inimigo interno. Esse inimigo tem idade, cor, sexo e classe específica e pode ser encontrado sempre em território que agora passa a ser pacificado pelas forças do Estado. A população dessas áreas é sempre composta por potenciais delinquentes ou seus cúmplices que devem ser vistos sempre com desconfiança. E, para o bem da própria comunidade e áreas pacificadas, é preciso que se instale um regime autoritário para se resgatar a lei e a ordem. As violações às garantias mais básicas são vistas como necessárias por estarem em um momento de emergência e os abusos são entendidos como danos colaterais - indesejados, porém legítimos em prol da causa maior.

Por isso defendemos que a política criminal deve ser pautada por um novo paradigma da segurança. Em primeiro lugar, rechaçar a ideia de inimigo, pois dela inevitavelmente se expande o poder punitivo ilimitadamente. Em 
segundo lugar, a partir da negação da ideia de inimigo e reconhecimento do status de cidadão, sujeito das garantias constitucionais, nasce a noção de uma polícia como prestadora de serviço e não como força de combate. Dessa forma, é possível estabelecer uma política de segurança pública baseada na prevenção dos delitos ao invés de sua repressão, proporcionada por uma polícia comunitária que se aproxima da população e constrói com a mesma as práticas e diretrizes a partir da compreensão das necessidades de cada comunidade, entendendo que o fenômeno da delinquência não é somente criminal, mas, antes de tudo, um fenômeno social que precisa ser entendido interdisciplinarmente para que se encontre a solução dos conflitos que se apresentam.

É a partir dessa proposta dinâmica de contenção do poder punitivo que será possível efetivar os preceitos constitucionais, promover a diminuição das diferenças sociais e garantir a dignidade de todos os cidadãos, além de resolver os conflitos sem a intervenção penal. O caminho não é curto e muito menos fácil. Aqueles que promovem e se beneficiam da sociedade excludente não vão abrir mão de seu poder e privilégios de maneira altruísta. É preciso paciência, serenidade e foco para promovermos mudanças que atinjam as mentes e corações da sociedade. No entanto, para aqueles que lutam e acreditam que as coisas podem ser melhores, para aqueles que têm o Estado Democrático de Direito ideal como norte, cada passo em direção a ele é uma conquista a mais. Os que recebem o título de utopistas não se calam diante dos arbítrios do poder punitivo. E no fim, venceremos. 
Que tristes os caminhos, se não fora A presença distante das estrelas!

( Mario Quintana - Das Utopias) 


\section{BIBLIOGRAFIA}

ANITUA, Gabriel Ignacio. Histórias dos pensamentos criminológicos. Rio de Janeiro: Revan, 2008.

ASSIS, Machado de. O alienista. São Paulo: FTD, 1999.

BARATA, Alessandro. Criminologia crítica e crítica do Direito Penal. Rio de Janeiro: Revan, 2011.

BATISTA, Nilo. Punidos e mal pagos: violência, justiça, segurança pública e direitos humanos no Brasil de hoje. Rio de Janeiro: Revan, 1990.

. Sobre a criminalização do funk carioca. In: BATISTA, Vera Malaguti (org). Tamborzão: olhares sob a criminalização do funk. Rio de Janeiro: Revan. 20123

BATISTA, Vera Malaguti. Dificies ganhos fáceis: Drogas e juventude pobre no Rio de Janeiro. Rio de Janeiro: Revan, 2003.

. O Alemão é muito mais complexo. In: BATISTA, Vera Malaguti (org). Paz armada. Rio de Janeiro: Revan. 2012 . O medo na cidade do Rio de Janeiro. Rio de Janeiro: Revan, 2003

BECCARIA, Cesare. Dos delitos e das penas. São Paulo: Martins Fontes, 2005.

BELTRAME, José Mariano. Todo dia é segunda-feira. Rio de Janeiro: Editora Sextante. 2014

BURGIERMAN, Denis Russo. O fim da guerra: A maconha e a criação de um novo sistema para lidar com as drogas. São Paulo: Leya, 2011.

DE CASTRO, Lola Aniyar. Criminologia da libertação. Rio de Janeiro: Revan, 2005.

DORNELLES, João Ricardo W. Conflito e Segurança: Entre pombos e falcões. Rio de Janeiro: Lumen Juris, 2008.

FOUCAULT, Michel. Vigiar e punir. Rio de Janeiro: Vozes, 2010. 
JAKOBS, Günther. e MELIÁ, Cancio. Direito penal do inimigo: noções e críticas. Porto Alegre: Livraria do Advogado, 2012.

JHERING, Rudolf von. A luta pelo Direito. Rio de Janeiro: Forense, 2011.

WACQUANT, Loïc. Punir os pobres: a nova gestão da miséria nos Estados Unidos. Rio de Janeiro: Revan, $3^{\mathrm{a}}$ ed., 2003.

. As prisões da miséria. Rio de Janeiro: Zahar, $2^{\mathrm{a}} \mathrm{ed} ., 2011$.

ZACCONE, Orlando. Acionistas do nada: Quem são os traficantes de drogas. Rio de Janeiro: Revan, 2011.

ZAFFARONI, Raúl Eugênio. E busca das pens perdidas. Rio de Janeiro: Revan, 1991.

. e BATISTA, Nilo. Direito penal brasileiro. Primeiro volume. Rio de Janeiro: Revan, 2003.

. O inimigo no direito penal. Rio de Janeiro: Revan, 2007.

ZIZEK, Slavoj. Violência. São Paulo: Boitempo , 2014.

\section{DOCUMENTOS RETIRADOS DA INTERNET}

Resolução 19/2011 da Assembleia Legislativa do Rio de Janeiro. Disponível em: http://www.marcelofreixo.com.br/files/2014/09/RelatorioCPI-Armas.pdf 